Article

\title{
Comparative Investigation of Total, Recoverable and Bioavailable Fractions of Sediment Metals and Metalloids in the Lagos Harbour and Lagoon System
}

\author{
Awwal Bamanga ${ }^{1,2, *}$, Nnamdi Henry Amaeze ${ }^{3}$ and Bader Al-Anzi ${ }^{2,4}$ \\ 1 School of Earth and Environmental Sciences, University of Portsmouth, Portsmouth PO13QL, UK \\ 2 Environmental Technology Department, Kuwait University, Kuwait City 13060, Kuwait \\ 3 Environmental Toxicology and Pollution Management Unit, Department of Zoology, University of Lagos, \\ Lagos 101017, Nigeria \\ 4 Department of Mechanical Engineering, Massachusetts Institute of Technology, 77 Massachusetts Avenue, \\ Cambridge, MA 02139, USA \\ * Correspondence: awwal.bamanga@port.ac.uk
}

Received: 6 July 2019; Accepted: 5 August 2019; Published: 11 August 2019

check for updates

\begin{abstract}
This study investigated and characterised concentration of some selected metals and metalloids (As, Cd, Cr, Cu, Co, Fe, Mn, Ni, Pb, Sn, V and $\mathrm{Zn}$ ) present in surface sediments of the Lagos Harbour (LH) and associated Lagos Lagoon (LG) system using a combination of metal extraction and analytical methods within 26 sampling sites including a control (Apese Lagoon, APL). Sampling was carried out using a Van-veen grab sampler on three occasions (dry seasons 2013, 2014; wet season 2013). The total, recoverable and bioavailable fractions were measured separately by $X$-ray fluorescence (XRF), Aqua regia (AR) extraction with inductively coupled plasma optical emission spectrometry (ICP-OES) and $1 \mathrm{M}$ hydrochloric acid $(1 \mathrm{M} \mathrm{HCl})$ extraction with inductively coupled plasma mass spectrometry (ICP-MS) analysis, respectively. Results were compared with National Oceanic and Atmospheric Administration (NOAA)/Canadian Sediment Quality Guidelines (CSQG) and geochemical spatial distribution maps. Threshold effect level (TEL) were exceeded by total concentration of $\mathrm{Cu}, \mathrm{Zn}$ and recoverable As across the lagoons. Bioavailable As was below TEL while $\mathrm{Ni}$ was associated with the ports in the LH.
\end{abstract}

Keywords: shipping activities; port dredging; sediment pollution; heavy metal fractions; geochemical distribution

\section{Introduction}

Heavy metal pollution in sediments of marine ecosystems has gained the increased attention of many environmental researchers over the past few decades. Heavy metals are natural constituents of sediments and can also be derived from anthropogenic sources, as they are incorporated into sediments as pollutants from industrial or urban releases and wastes [1]. Metals settled in sediments may be re-suspended and cause secondary contamination to the aquatic environment [2]. Sediments act as environmental archives that indicate the timeline of an aquatic environmental contamination [3]. While heavy metals may be transferred from water to sediments through settling of particles, their remobilization may occur via aquatic biota, as well as with changes in environmental conditions [4].

It is generally known that marine ecosystems are endangered by various contaminants, mostly untreated sewage, waste oils, plastics and industrial effluents that ultimately affect the sustainability of living resources and pose global environmental as well as public health risk [5,6]. This can be related to the classical assumption that the marine environment has an infinite capacity to absorb these contaminants without being subjected to undue harm [7]. However, the continued introduction of 
wastes into the marine environment can result in a measurable rise in the local level of contamination and this is of growing global concern in view of the threats to coral reefs and marine biota.

Marine pollution, specifically in coastal zones, has been an issue of growing especially with respect to the health of inhabiting animals. For example, significant ecotoxicological impacts and toxicity to inhabiting biota has been reported [8]. Conventionally, these coastal zones have been modified through processes of industrialisation and urbanisation, which include the development of large conurbations, harbours, and associated industrial activities, resulting in the deterioration of water and sediment qualities within the marine environment $[9,10]$. Among these activities, intensive industrial and shipping are dominant and involve the discharge of fertilizers and pesticides, human sewage, industrial and commercial municipal waste and oil spills into coastal areas [11].

The accumulation of metals in sediments from both natural and anthropogenic sources follows a similar process, thus making it difficult to identify and determine their origin [12]. Moreover, the total concentration of metals often does not accurately represent their characteristics and toxicity. To overcome these problems, it is helpful to evaluate the individual fractions of the metals to fully understand their actual and potential environmental effects [13]. Among the characteristics of heavy metals, mobility and bioavailability are crucial and depend strongly on the chemical and mineralogical forms [14] and concentrations in which they occur. Speciation studies are being conducted to determine different forms of heavy metals rather than their total metal content. These studies reveal the level of bioavailability of metals in harbour sediments and confirm that sediments are bio-indicators of heavy metal pollution in marine environments $[13,15,16]$.

Several studies have documented the occurrence, biogeochemistry, fate, distribution, and ecotoxicological effects of heavy metals in the Lagos Lagoon ecosystem [17-24]. However, [18] described that gaps and lack of data with no clear picture of the sources, pathways and impacts of these contaminants including quantification and fluxes from local and shipping activities. Further studies have, subsequently, described the sources of pollutants in the coastal areas of the lagoon [22]. Often, each coastal section is associated with unique activities that influences the local water quality and sediment ecology. Among these is Lagos Harbour (LH) which is associated with intense shipping activities, and the transfer of refined petroleum products to coastal jetties and industrial activities.

Lagos Harbour is a section of the Lagos Lagoon system which is directly associated with the Atlantic Ocean and routinely dredged to enhance vessel capacity of ports in Lagos. The closed nature of this harbour coupled with the various discharges from the ports makes it particularly vulnerable to pollutants such as heavy metals. To this end, the study was focused on determining the fractions of metals and their distribution in the Lagos lagoon system, including LH, the urbanized parts of the lagoon under the influence of inland rivers and the rest of Lagos (herein described as the Lagos Lagoon, LG) as well as a small isolated lagoon, Apese Lagoon (APL, which served as the control).

Although there have been numerous investigations of metals in the lagoon, none has been reported on differentiating the total from recoverable and bioavailable fractions. This is notable because although the Lagos Lagoon system is famed for its polluted status, the lack of concrete evidence on levels of bioavailable fractions casts a doubt on the potential impacts on polluting activities on the biota. Previous studies in the Lagos Lagoon system have often employed atomic absorption spectrophotometry (AAS) $[21,24,25]$ with the only published study on analysis of sediments using inductively coupled plasma optical emission spectrometry (ICP-OES) being that of [26]. The relevance of this lies in the comparative advantage of the use of multiple instrumentation rather than just in accurately presenting concentrations of the various fractions of heavy metals determined in sediment samples. More so, the vast majority of the surveys in the lagoon do not emphasize on sediment, rather the focus is mostly on the surface water metal concentrations $[27,28]$ using AAS analysis only.

The findings from the present study will clearly elucidate the fractions of selected metals and their specific pathways in order to improve the quality of available data and guide regulatory interventions based on well thought out empirical data. The combination of analytical methods used in this 
study would provide a more efficacious method for metal analysis which can be employed in future monitoring exercises of coastal water bodies in the region.

\section{Materials and Methods}

\subsection{Sampling Design}

The sampling sites for this study were selected based on prevailing activities such as shipping, sand mining, sawmill industries and recreational/residential within the lagoon serving as potential heavy metal pollution hotspots (Figure 1). The sampling sites comprised LH, the urbanised western shoreline of LG, and the separate APL as the control zone. Global positioning system (GPS) coordinates of each sampling site were taken and recorded in order to produce the spatial distribution maps. Twenty-six sampling sites were established within the study area and across the LH (sites: 1-16), LG (sites: 17-23), and APL (sites: 24-26) with three samples collected per site. Sampling was undertaken in 2013 for dry season 1 (DS1) and 2014 for wet season (WS) and dry season 2 (DS2) sampling. The sampling sites at APL were not established during the DS1 sampling regime, hence no data was produced in this location for this season due to logistical issues.

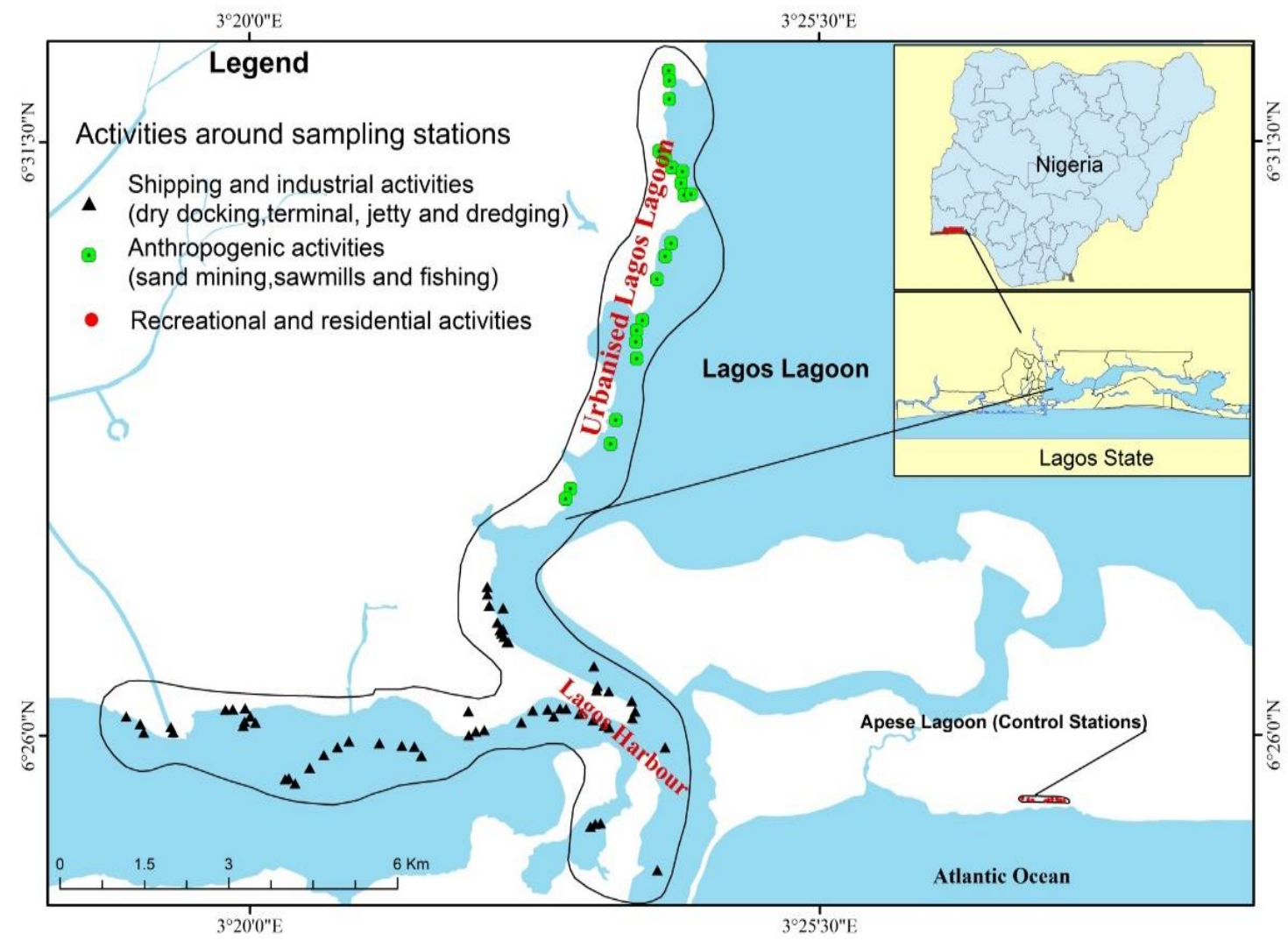

Figure 1. Sampling sites showing hotspots/activities around the study areas (Lagos Harbour, urbanised (western) part of Lagos Lagoon and Apese Lagoon (Control).

\subsection{Collection of Sediment Samples}

Surface sediments $(1-5 \mathrm{~cm})$ samples were collected at the selected sites using a $0.1 \mathrm{~m}^{2}$ Van-Veen Grab (wt. $25 \mathrm{~kg}$; height-20 cm) and the coordinates marked with the use of a hand-held GPS device (Magellan, Sport rack PRO MARINE [IEC-IPX7 Model]). A total of 78 samples were collected and pooled into 26 based on composite sediment samples ( 3 successful grab hauls) collected for each site. The haul was preserved for physical, chemical and other analyses in polytetrafluoroethylene (PTFE) bottles, bagged and stored in an ice chest cooler at $4 \pm 2{ }^{\circ} \mathrm{C}$ on site prior to analysis. Samples were transported and analysed at University of Portsmouth, UK. 


\subsection{Total Metals and Metalloids Analysis Using X-ray Fluorescence (XRF) Spectrometry}

Total metal and metalloid concentrations in sediment samples were analysed using X-ray fluorescence (XRF) technique based on the method described in the US Environmental Protection Agency (US-EPA) Method 6200 (1998). The XRF instrument was calibrated using a variety of international Certified Reference Materials (CRMs) powder pills. Powders are prepared for XRF analysis by fusing $5 \mathrm{~g}$ of sediment with $1 \mathrm{~g}$ of binder (Cereox wax binder) by mixing thoroughly for the sample to bind. The sediment samples were then put into the pestle mortar and mixed thoroughly to reach homogenised state with the binder. The pestle was pressed together with the sample and then placed into hydraulic tube and pressed again for $20 \mathrm{t} / \mathrm{sq}$. range and left for $45 \mathrm{~s}$. The pestle was then taken out and press turned over and the metal column was placed on top before placing it back into the hydraulic press to release the pellet. Finally, the samples were labelled with the sample name, date and analyzed using XRF.

\subsection{Recoverable Metals and Metalloids (Aqua Regia—Inductively Coupled Plasma Optical Emission Spectrometry, ICP-OES) Analysis}

Extraction and analysis of recoverable metals and metalloids from the sediment samples was carried out using the method described by the National Water Research Institute [29] version 5.7 similar to the US-EPA Method 3051 and the Ontario Ministry of the Environment's Aqua regia Method HMARSOIL-E3062A. Specifically, $0.5 \mathrm{~g}$ of sediment samples were weighed, before adding the acids in combination as: $2 \mathrm{~mL}$ conc. $\mathrm{HCl}+9 \mathrm{~mL}$ conc. $\mathrm{HNO}_{3}+1 \mathrm{~mL} \mathrm{30} \%$ hydrogen peroxide, the mixture then heated at $200{ }^{\circ} \mathrm{C}$ for $15 \mathrm{~min}$ in a high-pressure microwave oven. The samples were further diluted with deionised water $(12 \mathrm{~mL})$ to make it up to $24 \mathrm{~mL}$ volume of acids and deionised water and then filtered before finally being analysed using inductively coupled plasma optical emission spectrometry (ICP-OES). The instrument was calibrated using a preparation of standard dilution stock solution (100 mg/L). The calibration used was $0,10,20,50 \mathrm{mg} / \mathrm{L}$ for low concentration range. International Certified Reference Materials (CRM); HR-1 and PACS-2 which are references of known standards for the purpose of quality control, as well as acid blanks, were analysed in triplicate using the same procedures as for the samples under investigation.

\subsection{Determination of Bioavailable Metals and Metalloids (1M Hydrochloric Acid Inductively Coupled Plasma Mass Spectrometry, $\mathrm{HCl}-\mathrm{ICP}-\mathrm{MS}$ )}

Bioavailable metals and metalloids in the sediment samples were determined using a $1 \mathrm{M} \mathrm{HCl}$ extraction and analysis with inductively coupled plasma mass spectrometry (ICP-MS), as described by [30]. This method is similar to that currently adopted in Australia and New Zealand in terms of metal quantification for availability or labile in sediment in order to indicate the sediment quality [30]. Although it is not a perfect method just like any analytical procedure, it is commonly accepted for use in western countries, thus necessitating its selection for bioavailable metal assessment in the present study. The extraction process was based on timing, which was set for $4 \mathrm{~h}$ extraction from the time acids were added to the sample. Approximately $0.5 \mathrm{~g}$ sediment samples were weighed accurately (to four decimal places) and placed into a $15 \mathrm{~mL}$ centrifuge tube $0.5 \mathrm{~g}$. A triplicate of the acid blank labelled a 15 $\mathrm{mL}$ centrifuge tube "Blank1M" was used. In the fume cupboard, to each of the $15 \mathrm{~mL}$ centrifuge tubes $10 \mathrm{~mL}$ of $1 \mathrm{M}$ hydrochloric acid was added and mixed thoroughly. The lids were secured with the use of Parafilm to prevent leakages. The tubes were loaded in a rotating rack for $4 \mathrm{~h}$ then the samples were filtered through an acid washed pore size filter using a Swinnex filter housing and syringe. After that the sample was collected in a labelled $3 \mathrm{M}$ Sterilin tube and prepared to a 10 times dilution. Samples were then ready to be analysed using ICP-MS. All the sediment samples and reference materials, including blanks, were run in triplicate to adhere to quality control procedure. Two independent certified reference materials were analysed with the samples concurrently which represent excellent reference materials in regional comparisons of marine sediment pollution as demonstrated by [31]. 


\subsection{Spatial Distribution Analysis of the Heavy Metals}

WinGlink version 1.62 .08 software program was used to generate the geochemical contour maps. The interpolation radius and gridding values were varied to accommodate and properly represent the data variation and coverage. Meanwhile, the smoothing value was set to zero while the data positions were represented by dots. The generated maps were overlaid to scale on the map of the study area with AutoCAD in order to show the coastal line in relation to the data points. The sampling locations are not in the equal grids and results in irregular networks of sampling points. Therefore, geospatial kriging interpolation was used because it describes the spatial dependencies of the interpolated points by first analysing the spatial structure of the input data. A key use of kriging is determining the variability in depth of the sampled area which in this case can be attributed to natural coastal erosion and dredging activities which has distorted the sediment geology particularly in the Lagos harbour (LH). Also, kriging is useful in eliminating the problem of spread as sampling was done mostly in a linear pattern along the coastal areas associated with various anthropogenic activities (Figure 1).

In order to generate the contour maps, measured concentrations of the metals at different sampling sites together with their respective coordinates were computed into the software. The geographic information system (GIS) software is sets to scale for the various parameters inputted and uses such to generate contour maps using a range of colours to depict the relative spread of the metal concentrations across the sampled sites. The maps generated indicated accurately the spatial distribution of the respective metals thereby making it possible to associate concentrations with prevailing activities in the respective locations.

\subsection{Statistical Analysis of Results}

The results were presented as mean values of their respective zones, i.e., LH, LG and APL, in order to effectively compare them with existing standards. Significant differences between mean values were determined using analysis of variance (ANOVA) at $p<0.05$ while means were separated using least significant difference (LSD).

\section{Results}

\subsection{Total Metal and Metalloid Concentrations for Dry Season 1 (DS1), Wet Season (WS) and DS2}

The total metals analysed and compared with the threshold effect levels (TEL) of the National Oceanic and Atmospheric Administration (NOAA) and Canadian Sediment Quality Guidelines (CSQG) are presented in Figure 2a-c. In the DS1, the total of each heavy metal concentrations were higher in the LG than LH. The concentrations of Cu exceeded the TEL in LH and LG, while Zn exceeded the TEL in LG (Figure 2a). In the WS, As concentrations were higher in the LH compared to LG and APLwhile the concentrations of $\mathrm{Cu}$ exceeded the TEL in the three water bodies (LH, LG and APL). Zn on the other hand exceeded TEL consistently in all three sampling seasons only in the LG (Table 1). In the DS2 season, concentrations of Cu exceeded the TEL in all three water bodies (Figure 2c). 


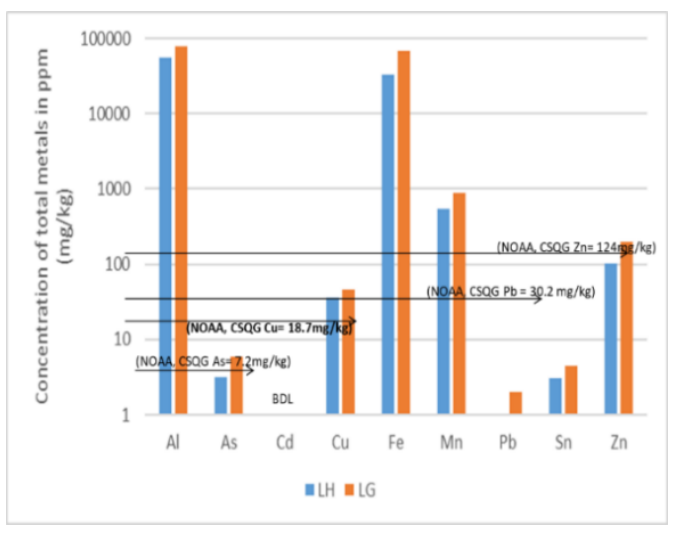

(a)

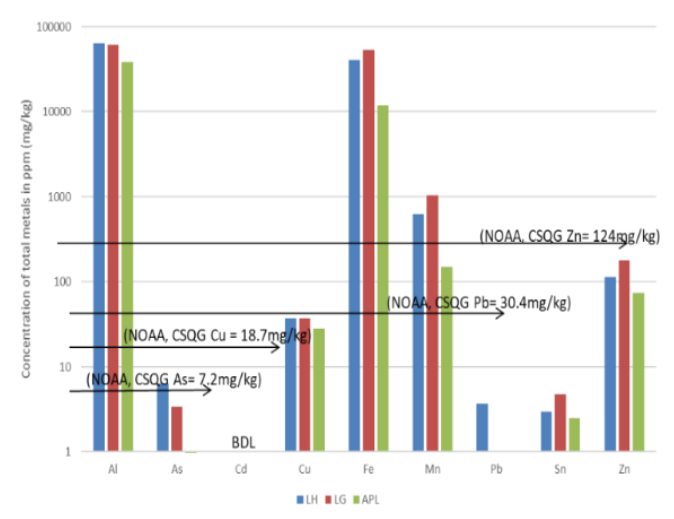

(b)

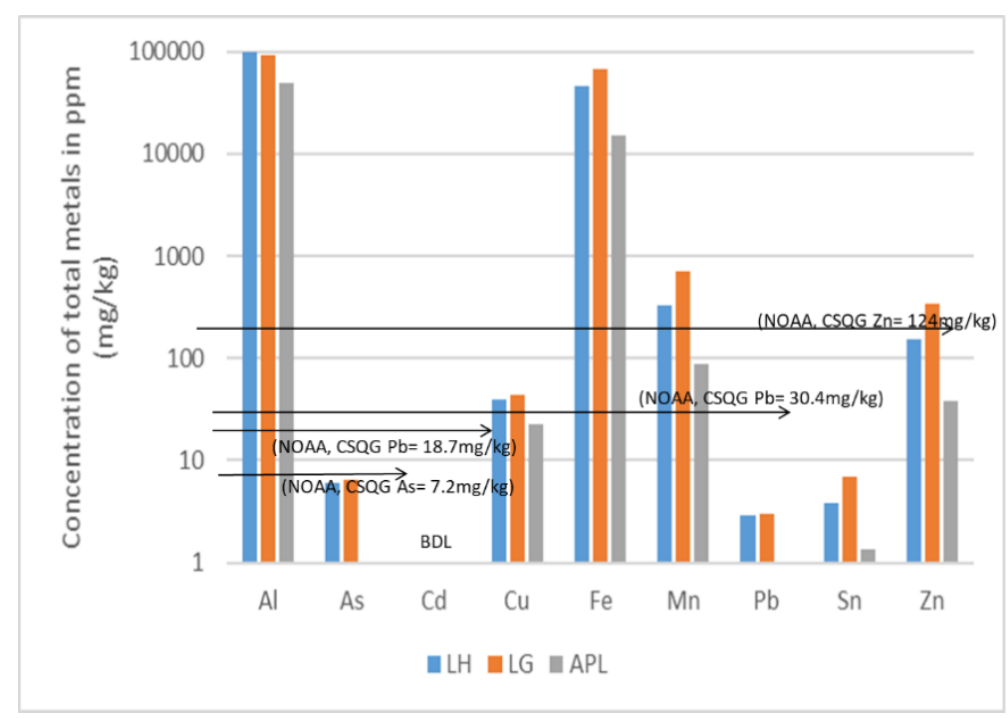

(c)

Figure 2. (a) Total metal and metalloid concentrations (X-ray fluorescence, XRF) for dry season 12013 (DS1-2013). (b) Total metal and metalloid concentrations (XRF) for wet season 2013 (WS-2013). (c) Total metal and metalloid concentrations (XRF) for DS2-2014. 


\subsection{Recoverable Concentrations for DS1, WS and DS2}

The recoverable metals concentration compared with the threshold effect level (TEL) of NOAA and CSQG are presented in Figure $3 \mathrm{a}-\mathrm{c}$. The recoverable metal concentrations were higher in the LG than LH in all three sampling seasons. The concentrations of recoverable As exceeded the TEL in at least one season of three water bodies (Table 1). Recoverable concentrations of As, $\mathrm{Cu}, \mathrm{Sn}$ and $\mathrm{Ni}$ all exceeded TEL in the DS2 as well as Sn in WS in the LH. Recoverable AS exceeded TEL in all three water bodies in the LG. Also Sn exceeded TEL in both dry seasons (DS1 and DS2) in the LG while the same was the case for $\mathrm{Cu}$ in the wet season. In the control, APL, recoverable As and Cu exceeded TEL as well.

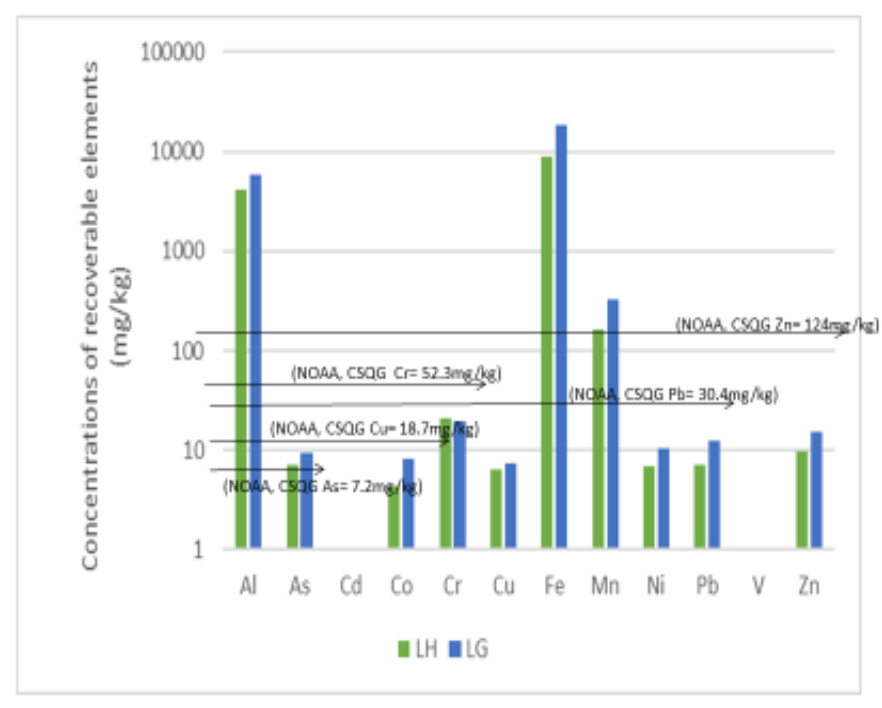

(a)

$$
10000
$$

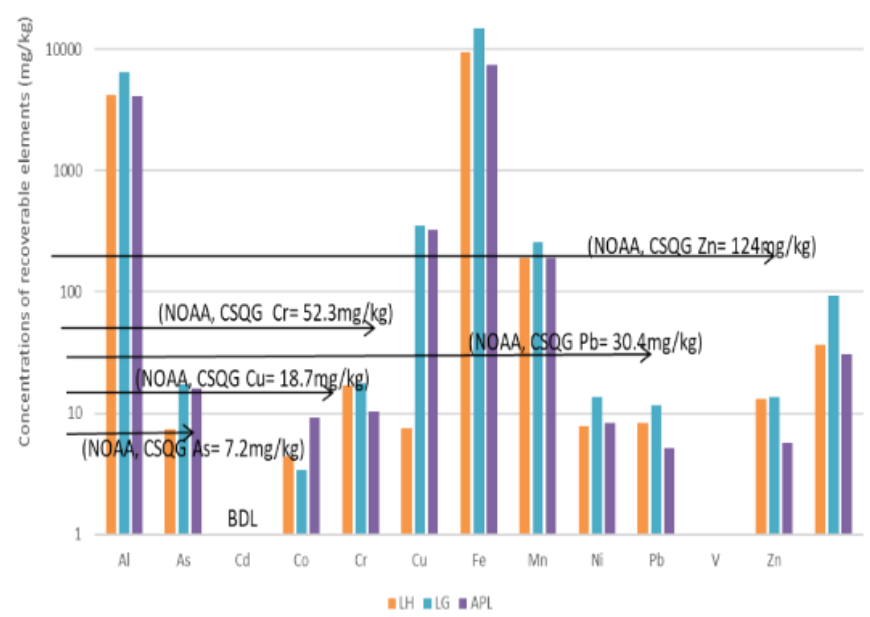

(b)

Figure 3. Cont. 


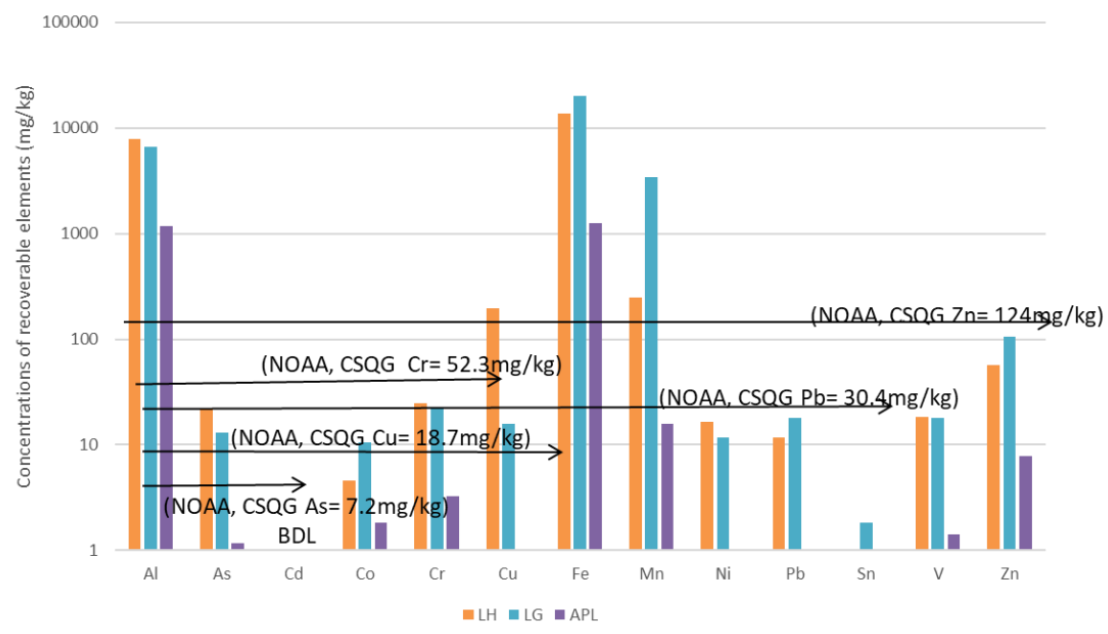

(c)

Figure 3. (a) Recoverable metals and metalloids (Aqua regia) for DS1-2013. (b) Recoverable metals and metalloids (Aqua regia) for WS-2013. (c) Recoverable metals and metalloids (Aqua regia) for DS2-2014.

\subsection{Bioavailable Concentrations for DS1, WS and DS2}

Bioavailable metals concentrations compared with the threshold effect level (TEL) of NOAA and CSQG are presented in Figure 4a-c. Unilke for recoverable metals and metaloids. levels of bioavailable $\mathrm{Co}$, Sn and V were below detection limit. As shown in Figure 4a, during the DS1, bioavailable metal concentrations were higher in the LG when compared to LH excpet concentrations of $\mathrm{As}, \mathrm{Cr}, \mathrm{Cu}$ and $\mathrm{Ni}$ that were higher in LH. The bioavilable metal concentrations were below the TEL across the sites- $\mathrm{LH}$ and LG, except for Ni which exceeded the TEL in LH well as Cd in the DS1 of the LG (Figure 4a).

In WS, on the other hand, the bioavailable metal concentrations were higher in the LH when compared to LG, exept for $\mathrm{Pb}$ and $\mathrm{Zn}$ that were higher in LG compared to LH and APL (Control). The metal concentrations were below the TEL across the sites except for Ni in LH and LG (Table 1).

In DS2, bioavailable metal concentrations were higher in the LH when compared to LG, except for $\mathrm{Mn}$ and $\mathrm{Zn}$ that were higher in LG compared to LH and APL. The metal concentrations were below the TEL across the sites in DS2 (Figure 4c).

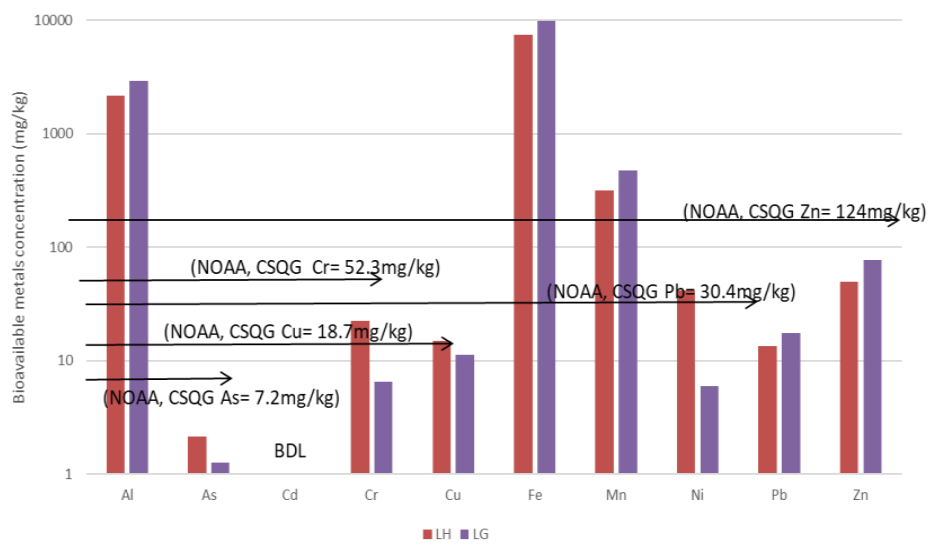

(a)

Figure 4. Cont. 


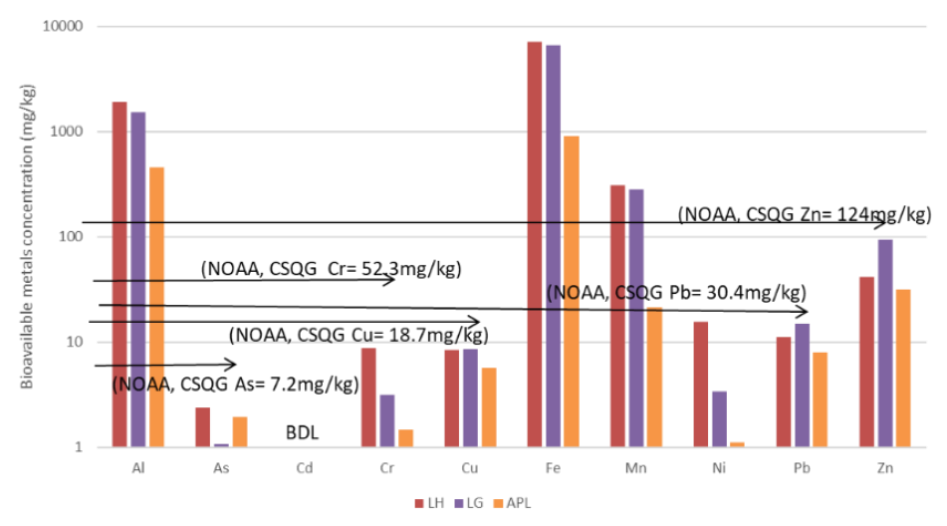

(b)

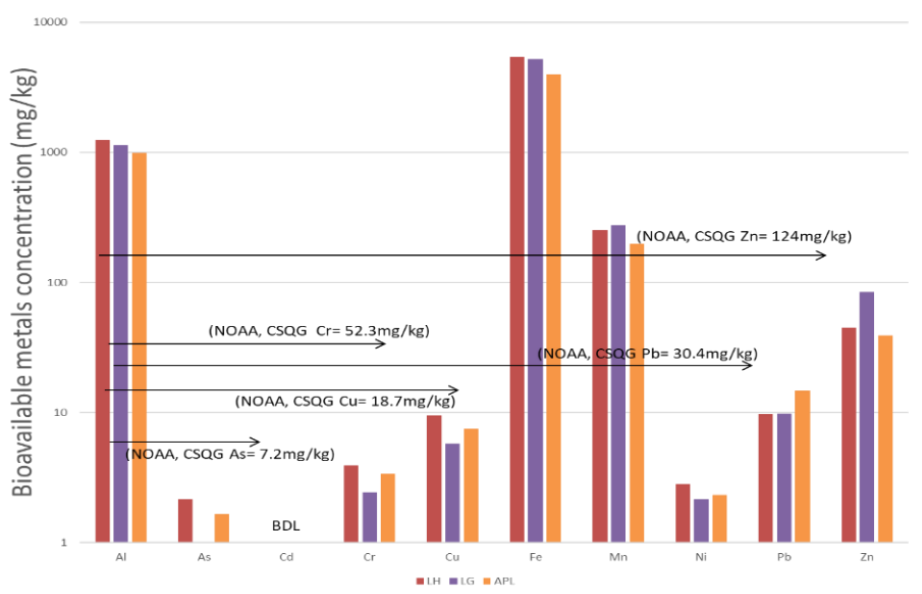

(c)

Figure 4. (a) Bioavailable metals and metalloids (1 M HCl) for DS1-2013. (b) Bioavailable metals and metalloids (1 M HCl) for WS-2013. (c) Bioavailable metals and metalloids for DS2-2014.

Table 1. Summary of metal contaminants which exceed sediment quality guidelines (SQGs) and their sources within the study area.

\begin{tabular}{|c|c|c|c|c|c|c|c|c|c|c|c|c|}
\hline \multirow[t]{2}{*}{ Location } & \multicolumn{9}{|c|}{ Methods and Elements } & \multirow{2}{*}{\multicolumn{2}{|c|}{ Sources }} & \multirow[t]{2}{*}{ Comments } \\
\hline & & Total (XRF & & & $\begin{array}{l}\text { ecoverab } \\
\text { qua Regii }\end{array}$ & & & $\begin{array}{l}\text { oavail } \\
\text { I M HC }\end{array}$ & & & & \\
\hline \multirow[t]{3}{*}{$\begin{array}{l}\text { Lagos } \\
\text { Harbour }\end{array}$} & $\begin{array}{l}\mathrm{Cu}, \\
\mathrm{Sn},\end{array}$ & $\begin{array}{c}\mathrm{Cu}, \\
\mathrm{Sn}, \mathrm{Zn}\end{array}$ & $\begin{array}{l}\mathrm{Cu}, \\
\mathrm{Sn}\end{array}$ & & $\begin{array}{c}\text { As, } \\
\mathrm{Cu}, \\
\mathrm{Sn}, \mathrm{Ni}\end{array}$ & Sn & $\mathrm{Ni}$ & $\mathrm{Ni}$ & $\mathrm{Ni}$ & $\begin{array}{l}1 . \\
2 . \\
3 . \\
4 .\end{array}$ & $\begin{array}{l}\text { Bulk cargo } \\
\text { offload/shipping } \\
\text { Petroleum } \\
\text { products spill } \\
\text { Industrial } \\
\text { Maintenance } \\
\text { dredging }\end{array}$ & $\begin{array}{c}\mathrm{Cu}, \mathrm{Sn}, \mathrm{Zn}, \mathrm{Ni} \\
\text { and As } \\
\text { exceeded the } \\
\text { NOAA/CSQGs } \\
\text { TEL }\end{array}$ \\
\hline & & Total (XRF & & & ecoverab & & & $\begin{array}{l}\text { oavail } \\
\text { I M H }\end{array}$ & & & & \\
\hline & DS1 & DS2 & WS & DS1 & DS2 & WS & DS1 & DS2 & WS & & & \\
\hline
\end{tabular}


Table 1. Cont.

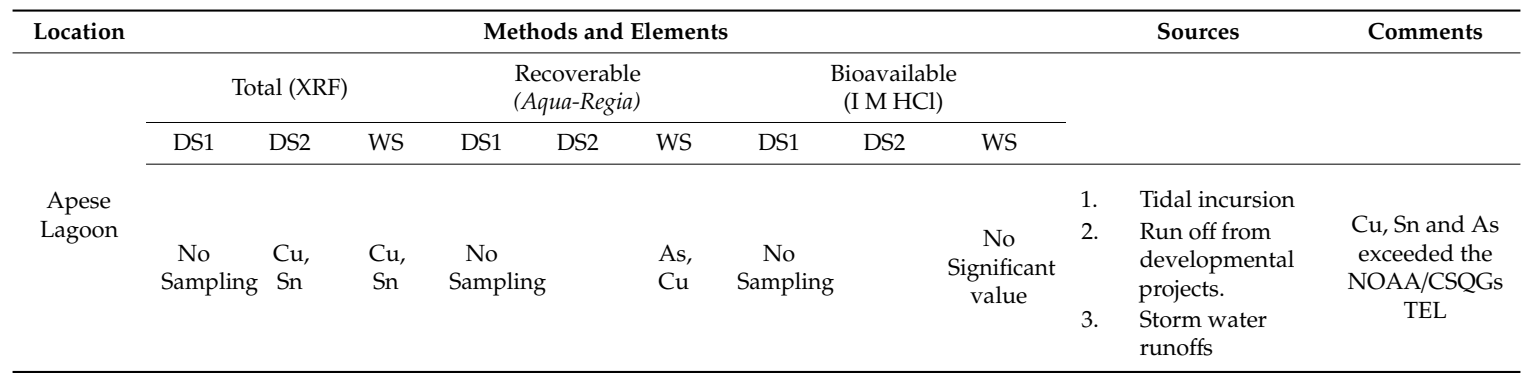

Key: TEL—Threshold effect level, DS—Dry season, WS—Wet season.

\subsection{Summary of the Polluting Activities and Relative Sediment Metal Concentrations}

The key polluting activities in the LH are activities associated with ports such as bulk cargo offload/shipping, petroleum products spill during transfer from tankers to coastal depots, discharge of industrial effluent as well as routine maintenance dredging of the channel. The LG was characterised by a diffused discharge of municipal sewage/runoff and industrial effluent discharge. Solid waste dumps are also common place in the coastal areas of the LG while artisanal sand mining occurs as well. As expected, the selected control lagoon, APL is only disturbed by storm water discharges and tidal incursion from the Atlantic Ocean (Table 1).

An integrated summary of the metals exceeding SQGs and their respective sources based on prevailing acitities in the areas which have been asociated with them by previous investigators elsewhere are presented in Table 1 . The metals As, $\mathrm{Cu}, \mathrm{Sn}, \mathrm{Zn}$ and Ni exceeded NOAA and CSQG threshold levels in both LH and LG. As, whereas Cu and Sn exceeded TEL at APL.

Specifically, in LH, the ranges of the metals and metalloids were were $0.00-64.44 \mathrm{mg} / \mathrm{Kg}$, 0.00-79.00 mg/Kg, $0.00-20.00 \mathrm{mg} / \mathrm{Kg}, 9.14-760.00 \mathrm{mg} / \mathrm{Kg}$ and $0.13-52.64 \mathrm{mg} / \mathrm{Kg}$ for As, Cu, Sn, $\mathrm{Zn}$ and Ni respectively. In the LG the metal ranges were $0.00-35.00 \mathrm{mg} / \mathrm{Kg}, 0.26-57.00 \mathrm{mg} / \mathrm{Kg}$, $0.00-16.00 \mathrm{mg} / \mathrm{Kg}, 1.38-1199.00 \mathrm{mg} / \mathrm{Kg}$ and $0.32-14.55 \mathrm{mg} / \mathrm{Kg}$ for the respective metals. Whereas in the APL, the ranges were $0.0-3.19 \mathrm{mg} / \mathrm{Kg}, 1.62-26.00 \mathrm{mg} / \mathrm{Kg}$ and $0.00-5.00 \mathrm{mg} / \mathrm{Kg}$ for the same metals.

Overall, there was no significant difference $(p>0.05)$ in $\mathrm{Cu}$ concentration in sediment samples across the sites. Sn and Zn concentrations showed significant differences $(p<0.05)$ in the sediments and LSD analysis indicated that the significant differences arose because of varions between LH and LG as well as LG and APL in both cases. There was no overall significant difference in sediment As concentrations across the water bodies but concentrations at LH were significantly different from APL. There was no significant difference in Ni concentrations across the sediment samples.

There was significant difference $(p<0.05)$ in the sediment concentrations of $\mathrm{Cu}$ in the LH and LG seperately compared to the control APL. With respect to $S n$, there was also a significant difference in concentrations between LH and LG as well as between LG and APL.

3.5. Geochemical Contour and Spatial Maps of Metal Distributions in Lagos Harbour (LH), Lagos Lagoon (LG) and Apese Lagoon (APL)

The different sites in the lagoons assessed were found to have a range of activities associated with them, some unique to them. These included port/reception facilities, shipping activities, refined petroleum products receiving and distribution depots, vessel maintenance docks, fishing and dredging activities in the LH areas. At the urbanized sections of the LG, prevailing activities along the coastline includes solid waste dumps, discharge of municipal runoffs and domestic wastes from point and diffused sources, log transportation and saw milling, effluent discharge among others. The control, APL, is characterized by recreational activities and sea water incursion at high tide.

The geological contour maps represented by the three methods of $(\mathrm{XRF}$, Aqua regia and $1 \mathrm{M} \mathrm{HCl})$ analysis and metals extraction employed and the distribution of selected metal analyte across the $\mathrm{LH}$, LG and APL (control site) (Figures 5a-c and 6a-c). The contour maps showed the spatial variations in 
the concentration of the metals and metalloids across the study area in each of the season based on the scales in the respective contour maps. The significant metals/metalloid presented in the contour maps are $\mathrm{As}($ Figure $5 \mathrm{a}-\mathrm{c}$ ) and $\mathrm{Pb}($ Figure $6 \mathrm{a}-\mathrm{c}$ ). They were selected due to the fact that they are known metals of health concerns and their sediment concentrations were considerably high, and sometimes higher than the NOAA and CSQG standards/safe limits of heavy metals in marine sediments. Although Pb did not exceed the TEL on the average, it was further investigated for its spatial distribution based on current knowledge of its toxicity at low levels of exposure.

Specifically, the idea was to further evaluate the distribution of two non-biologically relevant metals and two essential ones that are biologically relevant at low concentrations. The contour maps revealed varied concentrations (from very high to low) of the both sediment heavy metals distributed in the LH and LG in the three sampling seasons. The control (APL) generally showed low to insignificant concentrations of the heavy metals distributed in the sediments for both WS and DS2 (Figures 5a-c and $6 \mathrm{a}-\mathrm{c})$.

Generally recoverable and bioavailable As were higher in the LH compared to the LG while total As was higher in LG, although it showed considerable presence in the LH (Figure 5a-c). The recoverable As concentrations were however below TEL except for DS2 (Figure 5c). All Pb concentrations did not exceed TEL. With respect to $\mathrm{Pb}$, total concentration in the sediment was higher in $\mathrm{LH}$ in areas associated with petroleum products tranfer activities during DS1 (Figure 6a) and WS (Figure 6b), while in DS2 it was higher in the LG around the entry point of major municipal runoff canal (Figure 6c). Recoverable and bioavilable forms of $\mathrm{Pb}$ were generally higher in the LG compared to LH except for bioavailable forms in DS1 where the reverse was the case (Figure 6a-c). 


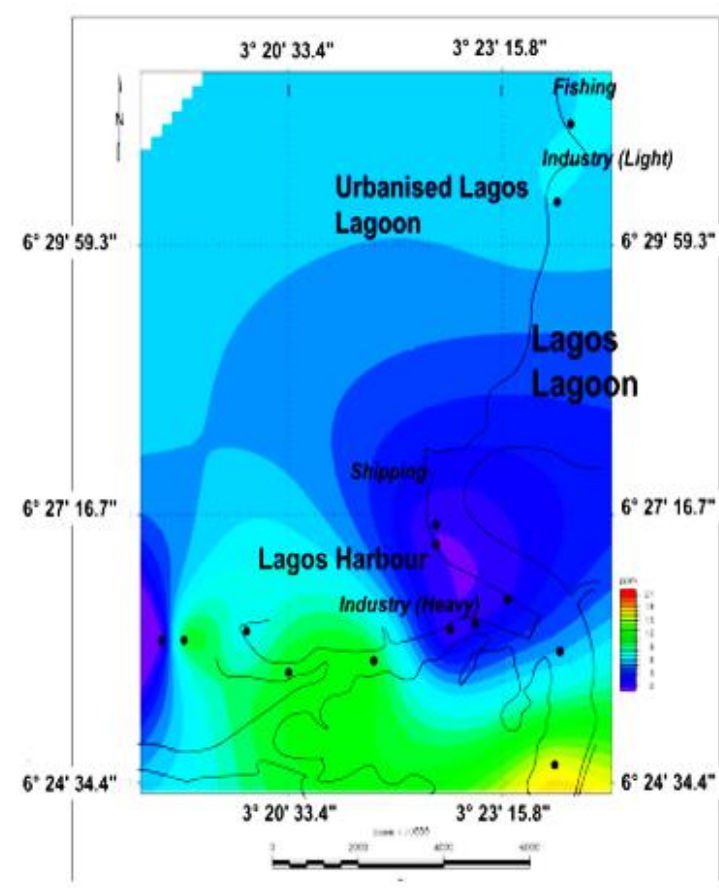

Total As (XRF)

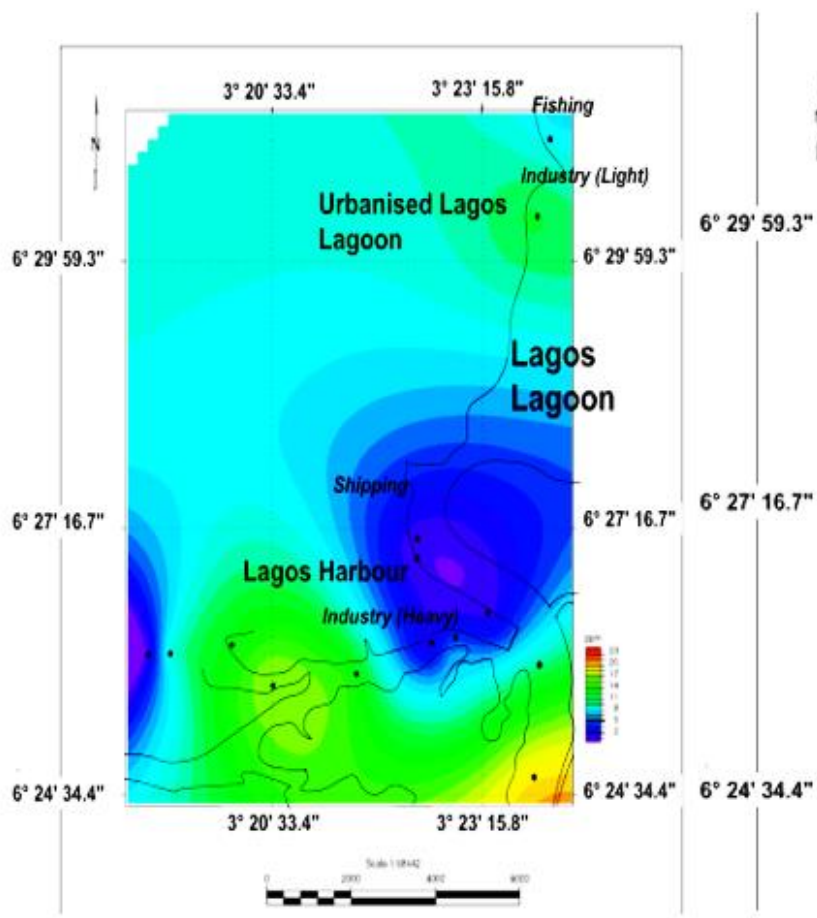

Recoverable As (Aqua regia)

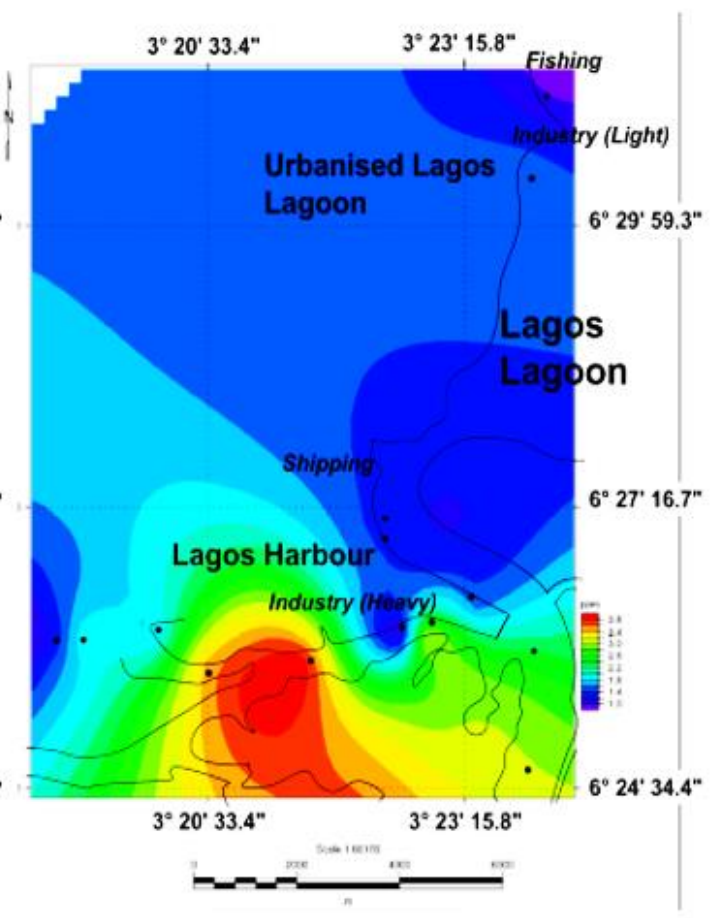

Bioavailable As (1 M HCl)

(a)

Figure 5. Cont. 


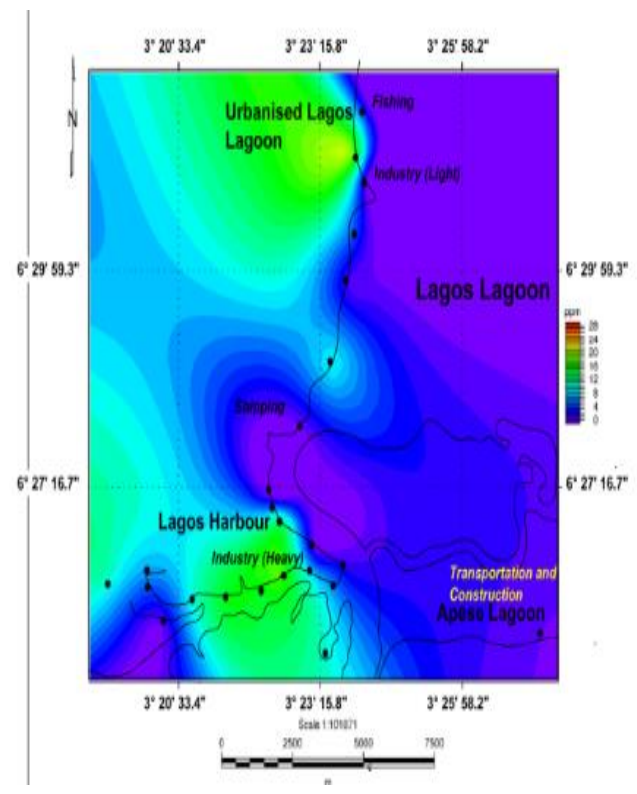

Total As (XRF)

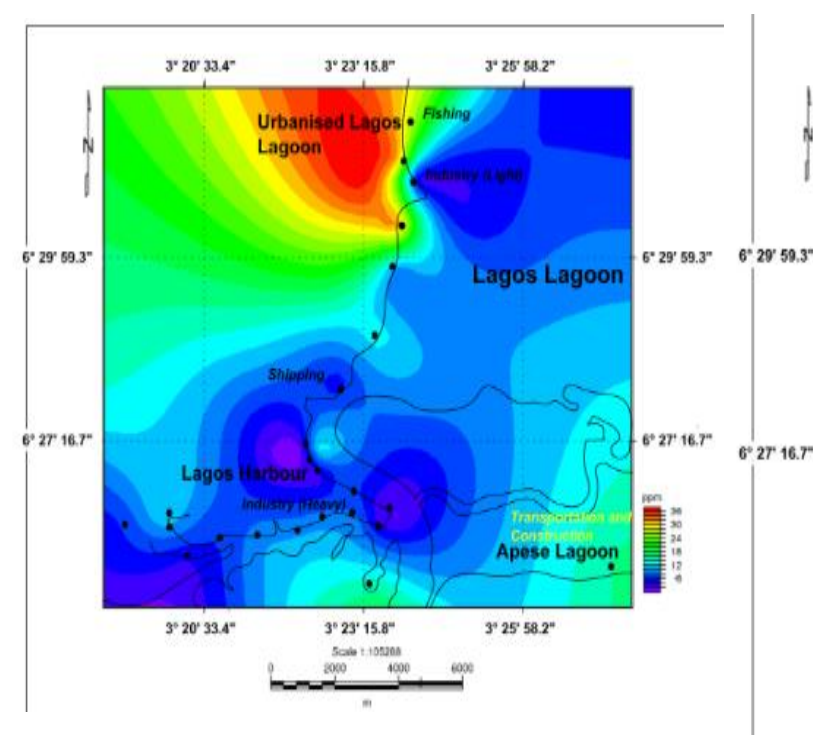

Recoverable As (Aqua regia)

(b)

Figure 5. Cont.

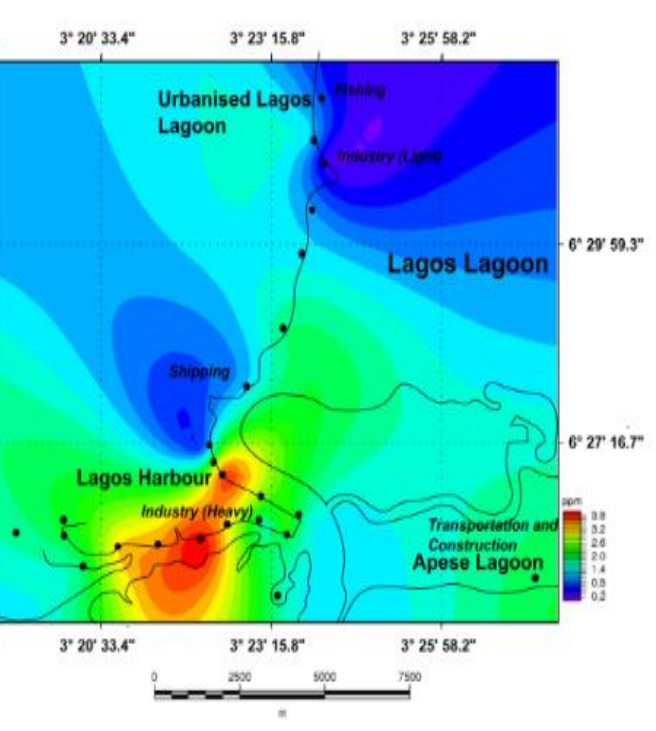

Bioavailable As (1 M HCl) 


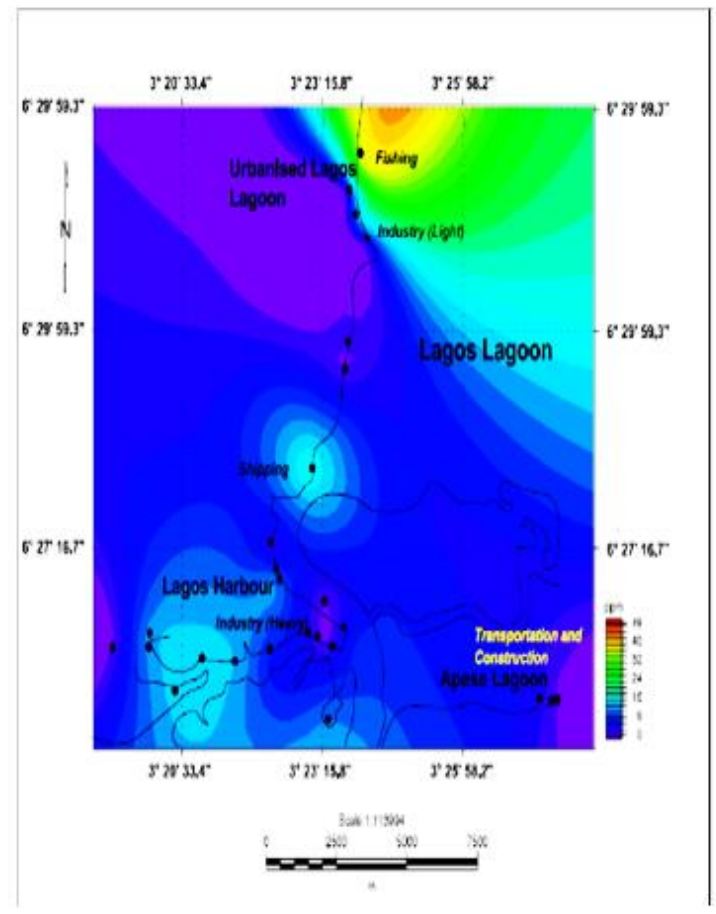

Total As (XRF)

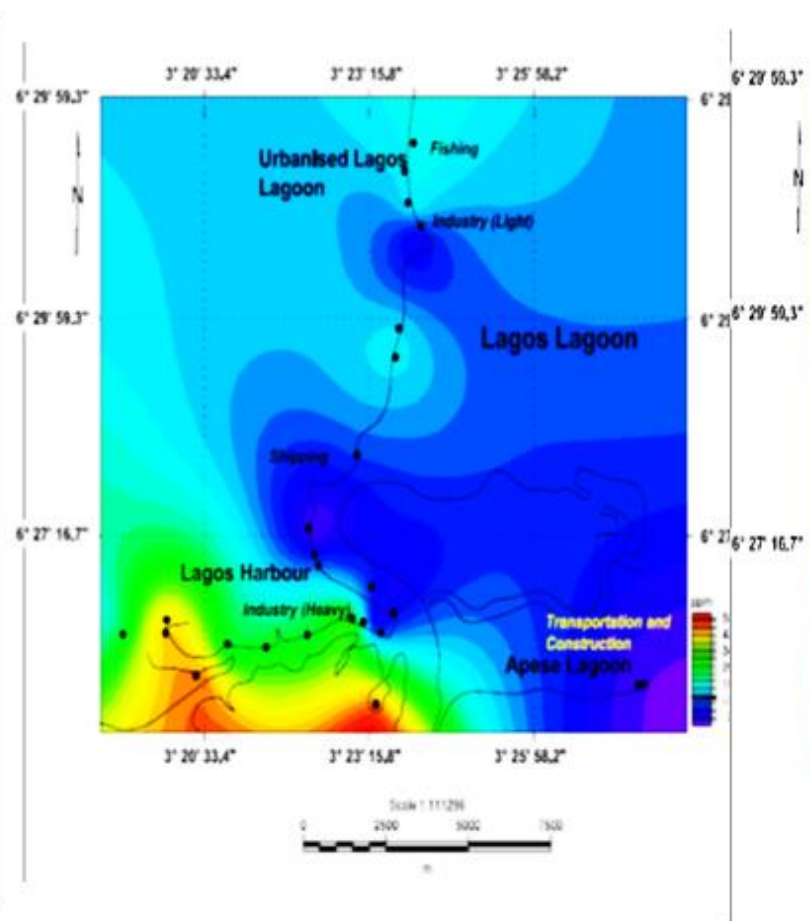

Recoverable As (Aqua regia)

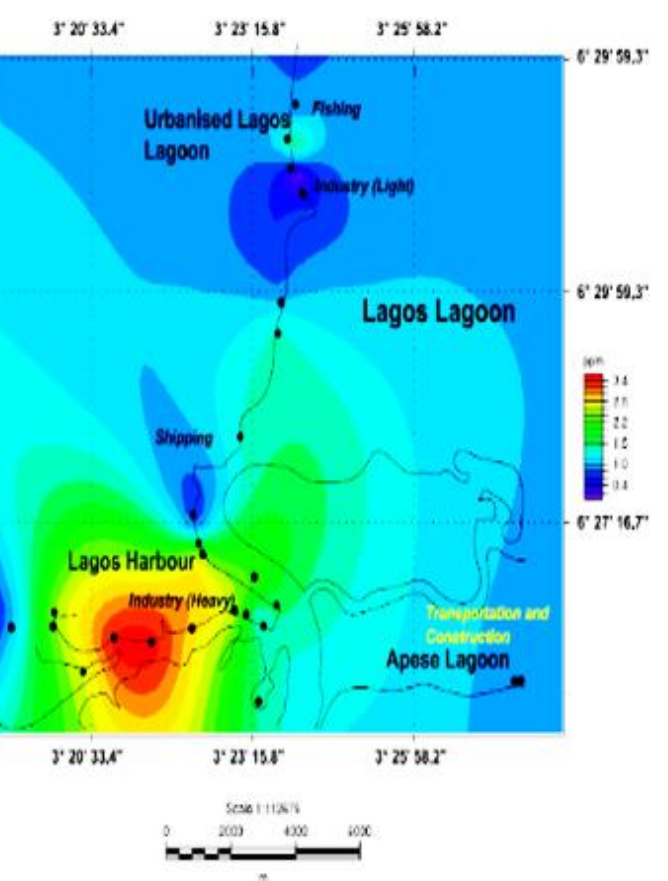

Bioavailable As (1 M HCl)

(c)

Figure 5. Spatial variations in the total, recoverable and bioavailable as distributed in sediment across the Lagos Harbour, Lagos Lagoon and Apese Lagoon (a-DS1, b-WS2, c-DS2). 


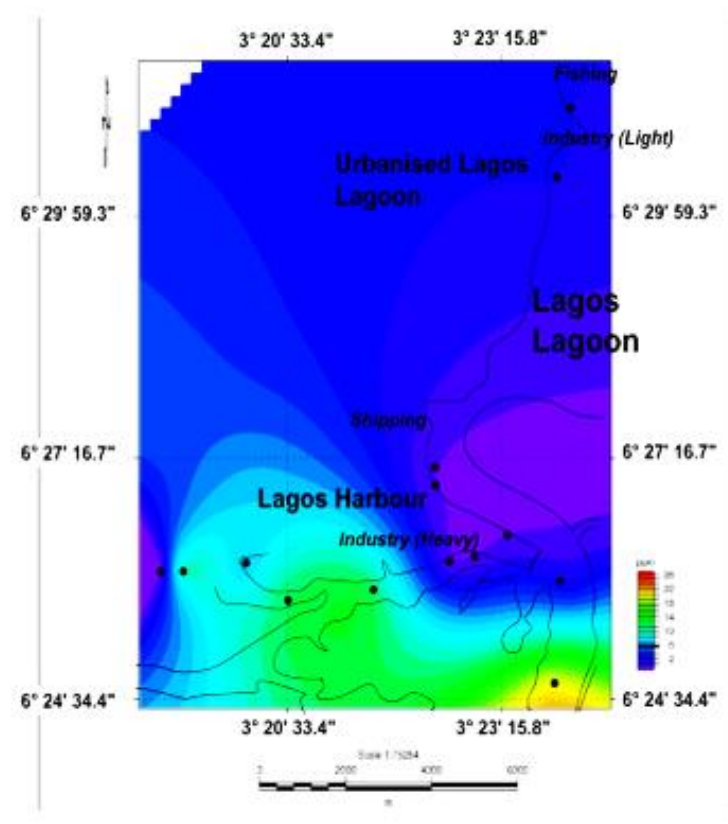

Total Pb (XRF)

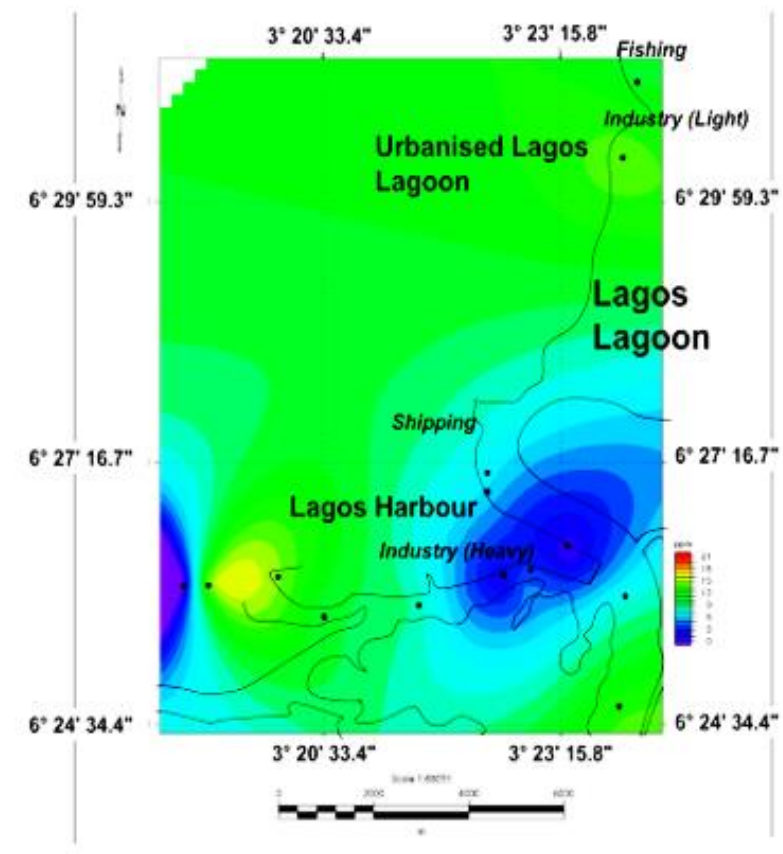

Recoverable $\mathrm{Pb}$ (Aqua regia)

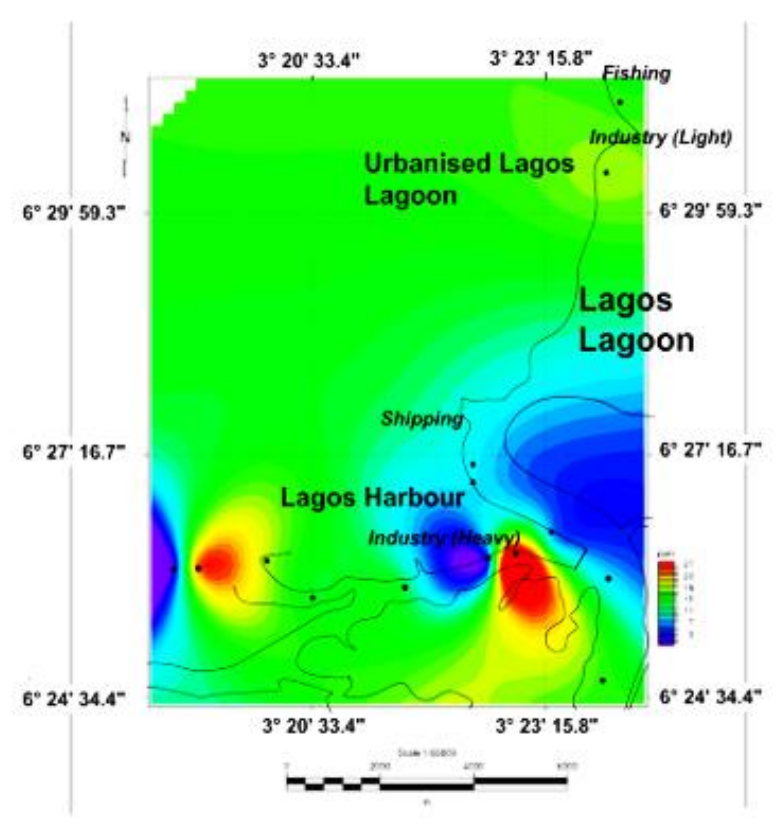

Bioavailable $\mathrm{Pb}(1 \mathrm{M} \mathrm{HCl})-$

(a)

Figure 6. Cont. 


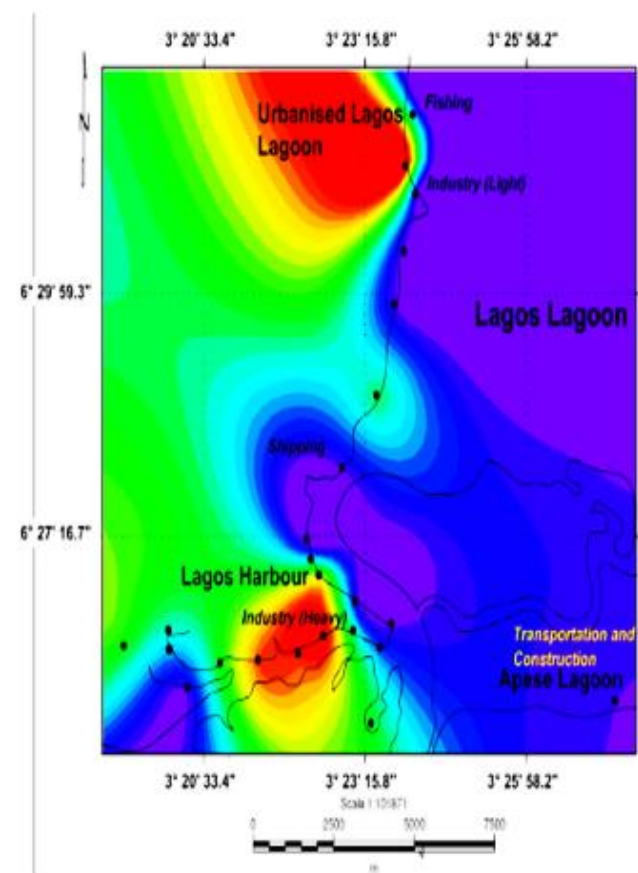

Total Pb (XRF)

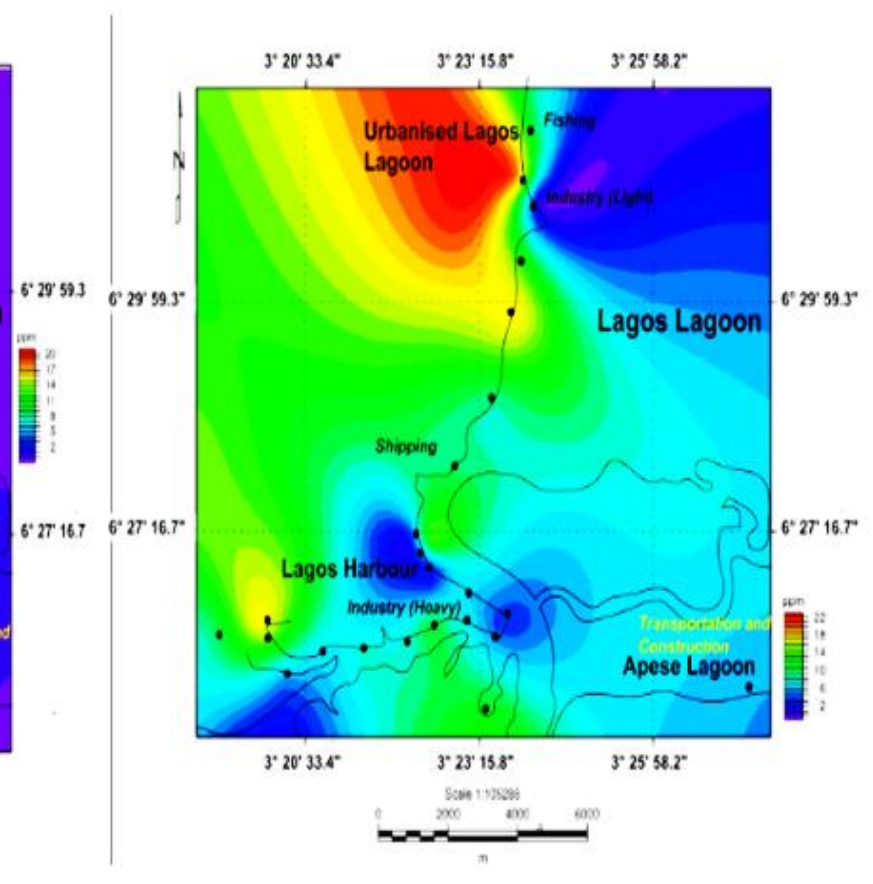

Recoverable $\mathrm{Pb}$ (Aqua regia)

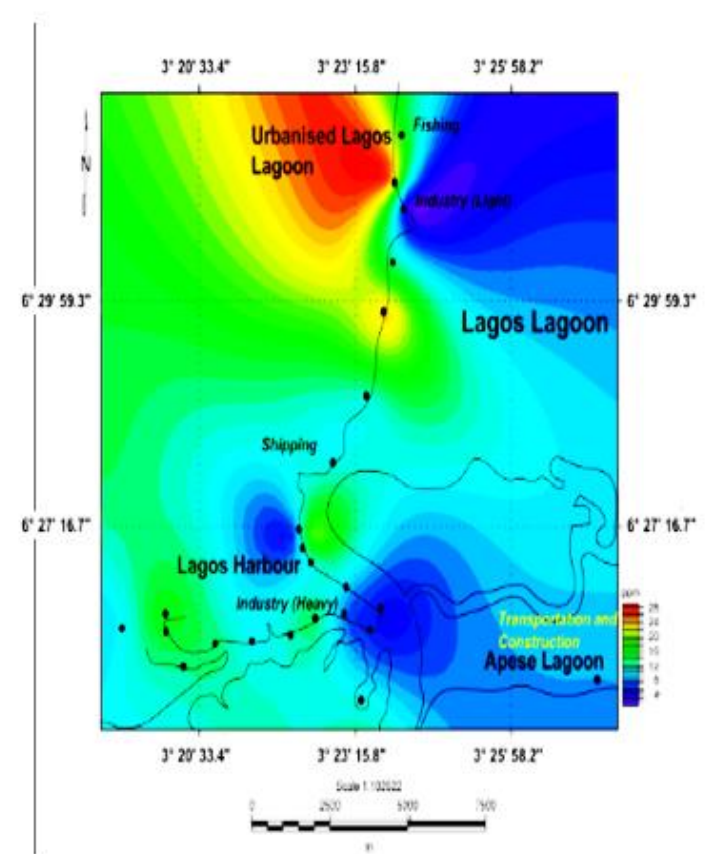

Bioavailable $\mathrm{Pb}$ (1 M HCl)

(b)

Figure 6. Cont 


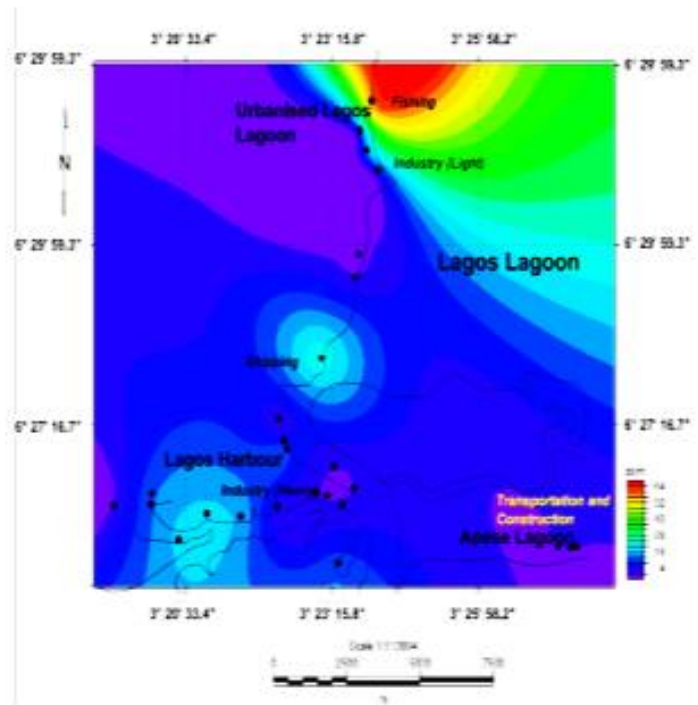

Total Pb (XRF)

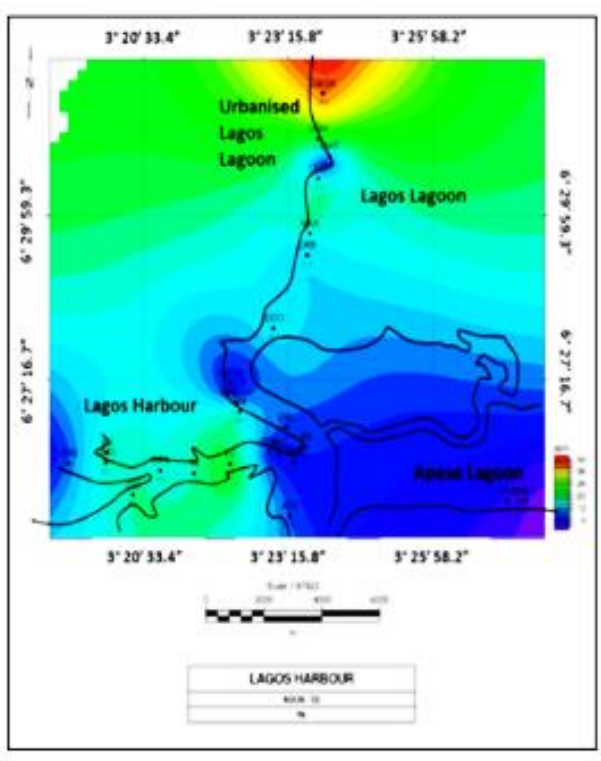

Recoverable $\mathrm{Pb}$ (Aaua reaia)

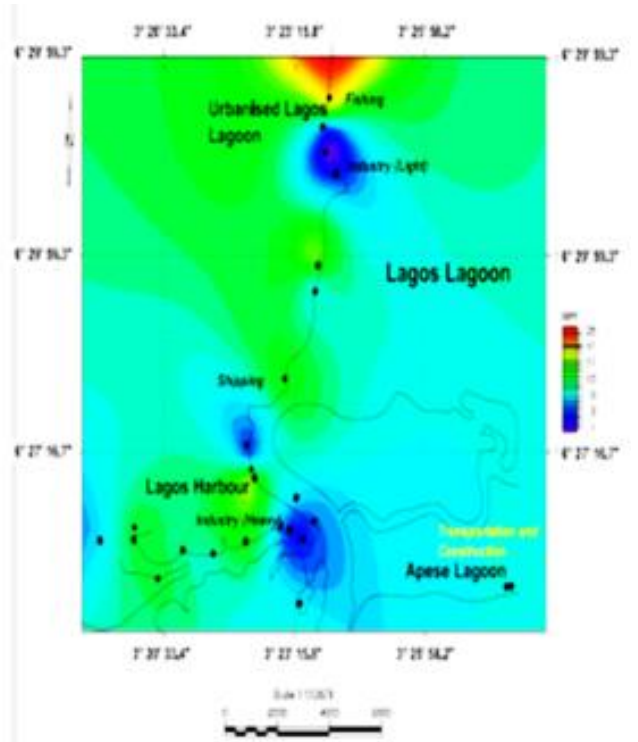

Bioavailable $\mathrm{Pb}$ (1 M HCl)

(c)

Figure 6. Spatial variations in the total, recoverable and bioavailable Pb distributed in sediment across the Lagos Harbour, Lagos Lagoon and Apese Lagoon (a-DS1, b-WS2, c-DS2). 


\section{Discussion}

The findings from this study has outlined the current status of sediment heavy metal fractions and therefore their risk of toxicity in the sediments of LH and the urbanized western LG. The toxicity of metals to aquatic biota inhabiting the Lagos Lagoon system is well reported [32-34] and this has been attributed to unregulated release of wastes into the water body. Coastal and estuarine sediments in industrial zones serve as the largest reservoir of metal contaminants in the marine ecosystem [35]. This occurrence is worrisome in view of the use of water bodies like the Lagos Lagoon system and its harbour as source of fish food for the city dwellers [25].

Metals have the ability to bioaccumulate and biomagnify along food chains, posing increasing threat to aquatic animals and humans in the process [36]. Therefore, understanding their levels and distribution is a key public health intervention particularly in industrialized and urbanized cities with characteristically closed harbour where shipping and industrial activities are co-located with commercial fishing. Although the granulometric composition of the sediment has considerable influence on its ability to bind with metals and retain them, the continued supply in the long term cannot be dissociated with prevalent coastal anthropogenic activities releasing their unique waste into the lagoon. The sediments were generally characterized by clay-silt and coarse materials which appeared to be similar for LH and LG despite prevailing coastal activities.

A key factor in metal quantification is the technique [37], given that different analytical methods have their pros and cons and at such must be applied in appropriate circumstances depending on the objective. Respective analytical methods may yield higher or lower levels of metals depending on sample preparation and sensitivity of equipment. For instance, ICP-OES and ICP-MS are very useful in measuring trace elements with little analytical turnover time and, therefore, offer more sensitivity and efficiency than AAS [37]. It has been reported that ICP-MS and ICP-OES offer more precision compared to GAAS (graphite furnace (or electrothermal) atomic absorption spectrometry) and not FAAS (flame atomic absorption spectrometry) [38]. More so, the extraction technique will depend on the desired fractions of a metal to be measured either as total, recoverable or bioavailable.

Despite the immutable progress so far made, the challenge of understanding the scale of metal pollution in the Lagos Lagoon system subsists due to among others poor understanding of the pathways of entry of specific metal types and their hotspots in the lagoon and more importantly lack of use of modern analytical equipment capable of allowing for comparison of specific percentages of metal fractions. While an atomic absorption spectrophotometer has been the gold standard of measuring sediment heavy metals in the Lagos Lagoon system [18,20,21,25], only one published study has employed ICP-OES [26]. Amaeze (2012, unpublished) noted considerable metal concentrations in the sediments of this water body as well using ICP-OES analysis only. There is no existing comparative data published with respect to the yields of different analytical techniques in the Lagos Lagoon and in many cases conclusions on toxicological risks is focused on recoverable concentrations only without recourse to understanding the fractions that are actually available for uptake by biota.

This study was, therefore, aimed at evaluating port sediments at the LH in comparison with the rest of the urbanized western LG and a control, APL, using XRF, ICP-OES and ICP-MS following analysis and extraction via Aqua regia (AR) and $1 \mathrm{M} \mathrm{HCl}$ for the two latter analyses. The findings from the analytical results indicated that XRF analysis consistently gave higher concentrations of the respective metals compared to the others because no extractions were involved, compared to the latter and results, therefore, include both acid soluble and non-acid soluble forms. XRF simply analyses total metal concentrations by physical interactions with atoms, dislodging electrons in their inner orbitals [37], and this reduces the chances of dilution while analysing all fractions of the metals compared to procedures involving initial extraction $\mathrm{AR}$ and $1 \mathrm{M} \mathrm{HCl}$ which focuses only on the acid soluble fractions of the metals and, therefore, yields lower concentrations. However, [39] noted in their comparative study of $\mathrm{Pb}$ and $\mathrm{Cd}$, that XRF determined concentrations reported lower or equal metals concentration compared to recoveries using ICP-AES and AAS. This can be attributed to the fact that AAS for instance can be employed after sample dry hatching technique which excludes much of the 
liquid content of analytes which is comparable to the zero liquid analysis involved in XRF while the sensitivity of ICP analysis enhances the ability to detect higher concentration of metals.

While AR extraction followed by ICP-OES was employed in analysing recoverable concentrations of the metals investigated in this study, $1 \mathrm{M} \mathrm{HCl} \mathrm{ICP-MS} \mathrm{was} \mathrm{used} \mathrm{to} \mathrm{detect} \mathrm{the} \mathrm{bioavailable} \mathrm{forms.}$ ICP-MS is particularly useful in analysis of levels of trace elements in various media [40]. Ideally, recoverable concentrations should be higher than bioavailable concentrations but that was not always the case in this study. The reason is attributed to the peculiarities of the ligands and complexes which bind some of these metals, limiting very high/effective recovery of analytes.

With respect to the specific metals and metalloids analysed, total $\mathrm{Cu}$ and $\mathrm{Sn}$ (i.e., by XRF analysis) were found to exceed the NOAA/CSQG TEL in all three water bodies while Zn exceeded TEL in the LG and LH. The bioavailable Ni concentration was notable in the LH as they exceeded the TELs in three quarters of the sampling season for both analyses combined. LH is notable for the presence of petroleum products depots and bulk cargo offloading from vessels along its coastline. Accidental spills or discharge of bilge water during offload from tanker can release $\mathrm{Ni}$ on a regular basis into the sediments given that $\mathrm{Ni}$ has been associated with heavy oil used by ships as fuel for their normal operations [41,42]. Ni is also released alongside $\mathrm{V}$ and other air pollutants via the emissions from ships [42]. Thus, its concentration is considerable in LH, especially in sites around the ports because of the high level of ship traffic. This implies that there is a need to improve ship fuel sources and bilge water disposal process in order to manage Ni levels and protect the LH sensitive microbenthic fauna from harm due to bioaccumulation of this metal. Likewise, high concentrations of Ni noted in coastal urban areas of the city of Patras in Greece have been attributed to shipping activities given the low industrial activity in the city [42]. The observed high total $\mathrm{Cu}$ concentration particularly in LG can be attributed to the diffused nature of waste water entering the urbanized sections of the Lagos Lagoon from canals, coastal dumpsites, runoffs and other diffuse sources. Cu release in coastal areas have been reported to originate from processes like mining activities, production of metals and electrical appliances, domestic pesticide use, leather processing and automotive brake pads [43]. High total $\mathrm{Cu}$ concentrations in the $\mathrm{LH}$ on the other hand can be attributed to discharges during bulk cargo offloading as well as leaching of anti-fouling paints [44].

More so, recoverable As concentration was consistently higher than the TEL the in the LG. The availability of As at a location has been attributed to the unsuitable disposal of electronic waste, industrial effluents, fertilizers and atmospheric depositions as described by Talbot and Chegwidden in [45], some of which were notably observed in many of the sampled locations in the LG. In the $\mathrm{LH}$, lower recoverable As concentrations were observed, and they were mostly concentrated around petroleum products' tank farms and transfer sites, indicating that spills of imported petroleum products at the ports are important contributors to its distribution in the lagoon. Recoverable As detected in the control area could be due to deposition via air or influx from the sea during high tide. Generally, measured As concentrations did not pose threats to biota as there were no bioavailable fractions. $\mathrm{Pb}$ was ubiquitous in the assessed samples, although its levels were below the compared TELs. The $\mathrm{Pb}$ contamination hotspots were the petroleum depot sections of $\mathrm{LH}$ and a section of the LG which serves a discharge point for municipal wastes. Petrol spillage from diverse diffused sources in urban areas can easily be moved into the urbanised sections of the lagoon (LG) alongside storm water $[46,47]$. Ecologically, the bioavailable concentrations of the metals are of greater concern because this clearly shows which fractions can be taken up by the biota, with the potential for bioaccumulation and/or toxic effects. In this regard, $\mathrm{Ni}$ is the most significant metal of concern in LH while in LG important considerations should be given to $\mathrm{Cd}$ as well, given that some of their bioavailable fractions exceeded TEL.

From the foregoing it is apparent that acid extraction enhances the detectability of trace elements in the sediment samples such that some metals which were below TEL before extraction become measurable after acid extraction and analysis. This is of particular interest as it implies that the routine monitoring of the harbour and other parts of the lagoon system must be done using multiple analytical 
techniques in order to enhance recovery and ensure accuracy of recommendations due to the findings. Deductions on threats to biota of detected metal concentrations based on recoverable concentrations as have always been done in the Lagos Lagoon over the years have reached erroneous conclusions on the threat to aquatic biota, thereby exaggerating the situation. Although continued efforts need to be made by the federal and state environmental regulators in ensuring effective waste treatment before discharge, monitoring of dredging activities in the LH and prohibition of dumping of refuse, the onus lies on the scientific community to generate appropriate data depicting the exact levels of threat posed by the metals detected in the sediment samples.

\section{Conclusions}

Lagos Harbour and the rest of the lagoon system have historically been under pollution pressure from coastal port activities and pollution discharges from the urban centres as well as industrial clusters. The results showed that the distributions of heavy metals are influenced by anthropogenic activities, with petroleum tank farm operations and cargo offload being the primary contributors of spills and discharges through which the metals enter the substratum in the LH. Monitoring of the pollution status in the sediments has often involved metal analysis but this has only been done to determine recoverable concentrations using mainly AAS. This does not tell the full story of the potential impacts on living organisms in the water body. Thus the present study has conducted a holistic survey of sediment heavy metals in these water bodies using a combination of metals that clearly highlighted the respective fractions of the metals including bioavailable $\mathrm{Ni}$ and $\mathrm{Cd}$ which are more relevant in toxicological and public health inferences.

The findings indicated significant concentrations of extractible and bioavailable metals in LH sediments compared to the international guidelines of NOAA and CSQG. The distribution of heavy metals showed higher concentrations in the LH sediments, followed by the urbanized part of LG, with minimal or low concentrations in the control zone (APL). Thus, future studies on this lagoon and similar water bodies should employ a combination of methods in order to obtain the true picture of the sediment heavy metal contamination status which poses specific threats to biota and to ensure sustainable management of such ecosystems.

Author Contributions: Conceptualization, A.B. and B.A.-A.; methodology, A.B.; software, N.H.A.; validation, A.B., B.A.-A. and N.H.A.; formal analysis, A.B.; investigation, A.B.; resources, A.B.; data curation, N.H.A.; writing-original draft preparation, A.B. and N.H.A.; writing—review and editing, B.A.-A.; visualization, B.A.-A.; supervision, B.A.-A.; project administration, A.B.; funding acquisition, A.B. and B.A.-A.

Funding: This research received no external funding.

Conflicts of Interest: The authors declare no conflict of interest

\section{References}

1. Sarkar, S.K.; Frančišković-Bilinski, S.; Bhattacharya, A.; Saha, M.; Bilinski, H. Levels of elements in the surficial estuarine sediments of the Hugli River, northeast India and their environmental implications. Environ. Int. 2004, 30, 1089-1098. [CrossRef] [PubMed]

2. Wardhani, E.; Roosmini, D.; Notodarmojo, S. Status of heavy metal in sediment of Saguling Lake, West Java. In Proceedings of the IOP Conference Series: Earth and Environmental Science-The First International Symposium on Green Technology for Value Chains, Tangerang, Indonesia, 3-5 October 2016; IOP Publishing: Bristol, UK, 2017; Volume 60, p. 012035.

3. Swarnalatha, K.; Letha, J.; Ayoob, S. Ecological risk assessment of a tropical lake system. J. Urban Environ. Eng. 2013, 7, 323-329. [CrossRef]

4. Davutluoglu, O.I.; Seckin, G.; Ersu, C.B.; Yilmaz, T.; Sari, B. Assessment of metal pollution in water and surface sediments of the Seyhan River, Turkey, using different indexes. Clean Soil Air Water 2011, 9, 185-194. [CrossRef] 
5. Naylor, R.L.; Goldburg, R.J.; Primavera, J.H.; Kautsky, N.; Beveridge, M.C.; Clay, J.; Folke, C.; Lubchenco, J.; Mooney, H.; Troell, M. Effect of aquaculture on world fish supplies. Nature 2000, 405, 1017. [CrossRef] [PubMed]

6. Muduli, P.R.; Vardhan, K.V.; Ganguly, D.; Abhilash, K.R.; Balasubramanian, T. Heavy metal contamination and risk assessment in the marine environment of Arabian Sea, along the southwest coast of India. Am. J. Chem. 2012, 2, 191-208.

7. Clark, R.B. Marine Pollution, 5th ed.; Oxford University Press: New York, NY, USA, 2000.

8. Valavanidis, A.; Vlachogianni, T. Metal Pollution in Ecosystems. Ecotoxicology Studies and Risk Assessment in the Marine Environment. Available online: https:/www.researchgate.net/profile/ Athanasios_Valavanidis/publication/236623174_Metal_Pollution_in_Ecosystems_Ecotoxicology_Studies_ and_Risk_Assessment_in_the_Marine_Environment/links/00b4952fba8bb82bbd000000/Metal-Pollutionin-Ecosystems-Ecotoxicology-Studies-and-Risk-Assessment-in-the-Marine-Environment.pdf (accessed on 6 August 2019).

9. Filipkowska, A.; Lubecki, L.; Kowalewska, G. Polycyclic aromatic hydrocarbon analysis in different matrices of the marine environment. Anal. Chim. Acta 2005, 547, 243-254. [CrossRef]

10. Knox, A.S.; Rinklebe, J.; Paller, M.H. Heavy metals in sediments and remediation technologies. In Proceedings of the 17th International Conference on Heavy Metals in the Environment, Guiyang, China, 22-26 September 2014.

11. Knox, A.S.; Paller, M.H. Contaminants in sediments-remediation and management. In Proceedings of the E3S Web of Conferences-16th International Conference on Heavy Metals in the Environment, Rome, Italy, 23-27 September 2012; EDP Sciences: Les Ulis, France, 2017; Volume 1, p. 02003.

12. Idris, A.M.; Eltayeb, M.A.; Potgieter-Vermaak, S.S.; Van Grieken, R.; Potgieter, J.H. Assessment of heavy metals pollution in Sudanese harbours along the Red Sea Coast. Microchem. J. 2007, 87, 104-112. [CrossRef]

13. Okoro, H.K.; Fatoki, O.S.; Adekola, F.A.; Ximba, B.J.; Snyman, R.G. A review of sequential extraction procedures for heavy metals speciation in soil and sediments. Sci. Rep. 2012. [CrossRef]

14. Baeyens, W.; Monteny, F.; Leermakers, M.; Bouillon, S. Evalution of sequential extractions on dry and wet sediments. Anal. Bioanal. Chem. 2003, 376, 890-901. [CrossRef]

15. Wepener, V.; Vermeulen, L.A. A note on the concentrations and bioavailability of selected metals in sediments of Richards Bay Harbour, South Africa. Water SA 2005, 31, 589-596. [CrossRef]

16. Khalid, M.; Mohamadein, L.I.; Saad, E.M.; Reda, F.; Mahmoud, S.A. Assessment of Heavy Metals Pollution Using Sediments and Bivalve Brachidontes variabilis as Bioindicator in the Gulf of Suez, Egypt. Int. J. Mar. Sci. 2016, 6, 1-12. [CrossRef]

17. Ajao, E.A. Review of the State of Pollution of the Lagos Lagoon. NIOMR Technical Paper No. 106; Nigerian Institute for Oceanography and Marine Research: Lagos, Nigeria, 1996.

18. Oyewo, E.O. Industrial Sources and Distribution of Heavy Metals in Lagos Lagoon and their Biological Effects on Estuarine Animals. PhD Thesis, University of Lagos, Lagos, Nigeria, 1998.

19. Markert, B.; Friese, K. Trace Elements: Their Distribution and Effects in the Environment; Elsevier: Amsterdam, The Netherlands, 2000.

20. Otitoloju, A.K. Joint Action Toxicity of Heavy Metals and their Bioaccumulation by Benthic Animals of the Lagos Lagoon. Ph.D. Thesis, University of Lagos, Lagos, Nigeria, 2002.

21. Don-Pedro, K.N.; Oyewo, E.O.; Otitoloju, A.A. Trend of heavy metal concentrations in Lagos lagoon ecosystem, Nigeria. West Afr. J. Appl. Ecol. 2004, 5, 103-114. [CrossRef]

22. Amaeze, N.H.; Egonmwan, R.I.; Jolaoso, A.F.; Otitoloju, A.A. Coastal environmental pollution and fish species diversity in Lagos Lagoon, Nigeria. Int. J. Environ. Prot. 2012, 2, 8-16.

23. Alo, B.; Olayinka, K.; Oyeyiola, A.; Oluseyi, T.; Alani, R.; Abayomi, A. Studies and transactions on pollution assessment of the Lagos Lagoon System, Nigeria. In Land/Ocean Interactions in the Coastal Zone of West and Central Africa; Springer: Cham, Switzerland, 2014; pp. 65-76.

24. Kafilat Adebola, B.A.; Joseph Kayode, S.; Adebayo Akeem, O. Integrated assessment of the heavy metal pollution status and potential ecological risk in the Lagos Lagoon, South West, Nigeria. Hum. Ecol. Risk Assess. Int. J. 2018, 24, 377-397. [CrossRef]

25. Ajagbe, F.E.; Osibona, A.O.; Otitoloju, A.A. Diversity of the Edible Fishes of the Lagos Lagoon, Nigeria and the Public Health Concerns Based on their Lead (Pb) Content. Int. J. Fish. Aquac. 2012, 4, 55-62. [CrossRef] 
26. Olatunji, A.S.; Abimbola, A.F. Geochemical evaluation of the Lagos Lagoon sediments and water. World Appl. Sci. J. 2010, 9, 178-193.

27. Babatunde, E.E.; Samuel, O.B. Comparative study of mercury accumulation in some brackish water fishes in a tropical lagoon and its adjacent creek in south western Nigeria. Afr. J. Environ. Sci. Technol. 2009, 3, 180-185.

28. Williams, A.B.; Edobor-Osoh, A. Assessment of trace metal levels in fish species of Lagos Lagoon. Assess. Trace Met. Levels Fish Species Lagos Lagoon 2013, 2, 1-5. [CrossRef]

29. NWRI (National Water Research Institute). Canada Centre for Inland Waters National Laboratory for Environmental Testing Certified Reference, Materials \& Quality Assurances Services (Version 5.7); NWRI: Burlington, ON, Canada, 2006.

30. Snape, I.; Scouller, R.C.; Stark, S.C.; Stark, J.; Riddle, M.J.; Gore, D.B. Characterisation of the dilute HCl extraction method for the identification of metal contamination in Antarctic marine sediments. Chemosphere 2004, 57, 491-504. [CrossRef]

31. Townsend, A.T.; Palmer, A.S.; Stark, S.C.; Samson, C.; Scouller, R.C.; Snape, I. Trace metal characterisation of marine sediment reference materials MESS-3 and PACS-2 in dilute $\mathrm{HCl}$ extracts. Mar. Pollut. Bull. 2007, 54, 236-239. [CrossRef]

32. Okoye, B.C.; Afolabi, O.A.; Ajao, E.A. Heavy metals in the Lagos Lagoon sediments. Int. J. Environ. Stud. 1991, 37, 35-41. [CrossRef]

33. Otitoloju, A.A. Evaluation of the joint-action toxicity of binary mixtures of heavy metals against the mangrove periwinkle Tympanotonus fuscatus var. radula (L.). Ecotoxicol. Environ. Saf. 2002, 53, 404-415. [CrossRef]

34. Otitoloju, A.A.; Don-Pedro, K.N. Establishment of the toxicity ranking order of heavy metals and sensitibity scale of benthic animals inhabiting the Lagos lagoon. West Afr. J. Appl. Ecol. 2002, 3, 31-41. [CrossRef]

35. Sharifuzzaman, S.M.; Rahman, H.; Ashekuzzaman, S.M.; Islam, M.M.; Chowdhury, S.R.; Hossain, M.S. Heavy metals accumulation in coastal sediments. In Environmental Remediation Technologies for Metal-Contaminated Soils; Springer: Tokyo, Japan, 2016; pp. 21-42.

36. Qiu, Y.W. Bioaccumulation of heavy metals both in wild and mariculture food chains in Daya Bay, South China. Estuar. Coast. Shelf Sci. 2015, 163, 7-14. [CrossRef]

37. Helaluddin, A.B.; Khalid, R.S.; Alaama, M.; Abbas, S.A. Main analytical techniques used for elemental analysis in various matrices. Trop. J. Pharm. Res. 2016, 15, 427-434. [CrossRef]

38. Baysal, A.; Ozbek, N.; Akman, S. Determination of trace metals in waste water and their removal processes. In Waste-Water Treatment Technologies and Recent Analytical Developments; Einschlag, F.S.G., Carlos, L., Eds.; Intech Open: London, UK, 2013; pp. 145-171.

39. Pyle, S.M.; Nocerino, J.M.; Deming, S.N.; Palasota, J.A.; Palasota, J.M.; Miller, E.L.; Hillman, D.C.; Kuharic, C.A.; Cole, W.H.; Fitzpatrick, P.M.; et al. Comparison of AAS, ICP-AES, PSA, and XRF in determining lead and cadmium in soil. Environ. Sci. Technol. 1995, 30, 204-213. [CrossRef]

40. Rasdi, F.; Bakar, N.; Mohamad, S. A comparative study of selected trace element content in Malay and Chinese traditional herbal medicine (THM) using an inductively coupled plasma-mass spectrometer (ICP-MS). Int. J. Mol. Sci. 2013, 14, 3078-3093. [CrossRef]

41. Santos-Echeandía, J.; Prego, R.; Cobelo-García, A. Influence of the heavy fuel spill from the Prestige tanker wreckage in the overlying seawater column levels of copper, nickel and vanadium (NE Atlantic Ocean). J. Mar. Syst. 2008, 72, 350-357. [CrossRef]

42. Manousakas, M.; Papaefthymiou, H.; Diapouli, E.; Migliori, A.; Karydas, A.G.; Bogdanovic-Radovic, I.; Eleftheriadis, K. Assessment of PM2.5 sources and their corresponding level of uncertainty in a coastal urban area using EPA PMF 5.0 enhanced diagnostics. Sci. Total Environ. 2017, 574, 155-164. [CrossRef]

43. Solomon, F. Impacts of copper on aquatic ecosystems and human health. Environ. Communities 2009, 15, $25-29$.

44. Srinivasan, M.; Swain, G.W. Managing the use of copper-based antifouling paints. Environ. Manag. 2007, 39, 423-441. [CrossRef]

45. Abiodun, O.A.; Oyeleke, P.O. Analysis and seasonal distribution of some heavy metals in sediment of Lagos lagoon using environmental pollution indices. Phys. Sci. Int. J. 2016, 10. [CrossRef] 
46. Kersten, M.; Garbe-Schönberg, C.D.; Thomsen, S.; Anagnostou, C.; Sioulas, A. Source apportionment of Pb pollution in the coastal waters of Elefsis Bay, Greece. Environ. Sci. Technol. 1997, 31, 1295-1301. [CrossRef]

47. Amaeze, N.H.; Adeyemi, R.O.; Adebesin, A.O. Oxidative stress, heats shock protein and histopathological effects in the gills of African catfish, Clarias gariepinus induced by bridge runoffs. Environ. Monit. Assess. 2015, 187, 172. [CrossRef]

(C) 2019 by the authors. Licensee MDPI, Basel, Switzerland. This article is an open access article distributed under the terms and conditions of the Creative Commons Attribution (CC BY) license (http://creativecommons.org/licenses/by/4.0/). 